\title{
Globalization and the Decline of the Welfare State in Less-Developed Countries
}

\author{
Nita Rudra
}

Is the welfare state withering away, or will it survive current globalization trends? ${ }^{1}$ Recent literature framing this academic debate has extolled the resilience of this institution, despite the pressures of international market integration. ${ }^{2}$ These studies have reversed doomsday scenarios from the 1980s and 1990s that contemplated the ultimate demise of the welfare state. ${ }^{3}$ Yet trends in welfare spending in developed and developing countries have diverged. During the past quarter century, globalization penetrated both groups. However, while the more developed countries were expanding resources devoted to this form of safety net, the average share of gross domestic product (GDP) allocated in a sample of fifty-three less-developed countries (LDCs) began much lower and fell lower still (see Figure 1). My analysis goes beyond existing studies by providing an original model of the determinants of welfare spending in LDCs. ${ }^{4}$ I focus on how globalization can affect rich and poor countries differently and present a model that includes a new measure of labor strength. I show that in the face of globalization labor in LDCs has been unable to

For help with various aspects of this article, I am grateful to Barry Ames, Mithun Dutt, Gary Dymski, Stephan Haggard, Nora Hamilton, Robert Kaufman, James Robinson, Peter Rosendorff, Samira Salem, Ravi Sundaram, Krish Sundaram, Cassandra Thomas, Quang Vuong, Leslie Wirpsa, Adrian Wood, and the editors and anonymous reviewers at $I O$. I am especially indebted to Hayward Alker and John Odell for their detailed and extremely helpful comments. I would also like to gratefully acknowledge the assistance of the Center for International Studies at the University of Southern California.

1. Economic globalization is operationalized by the level of international trade and the level of capital flows as a share of GDP.

2. See Bernauer and Achini 2000; Iversen and Cusack 2000; Hicks 1999; Rieger and Leibfried 1998; Garrett 1998; Garrett and Mitchell 1996; Rodrik 1998; Quinn 1997; Pierson 1996.

3. See Tyrell 1977; Brown 1988; Morris 1988; Sherer 1987; Ruggles and O'Higgins 1987; and Wicks 1987.

4. Bernauer and Achini 2000; Garrett 2001; Rodrik 1998 and $1997 \mathrm{~b}$; and Quinn 1997 are exceptions who include developing countries in their samples. This study, however, moves beyond these analyses in two very important ways: (1) LDCs are treated as conceptually distinct from developed countries; and (2) important institutional variables expected to affect welfare expenditures, such as labor power, are included. Note that after this paper was accepted for publication; Kaufman and Segura (2001) published an analysis of the effects of globalization on Social Spending in Latin America.

International Organization 56, 2, Spring 2002, pp. 411-445

(C) 2002 by The IO Foundation and the Massachusetts Institute of Technology 


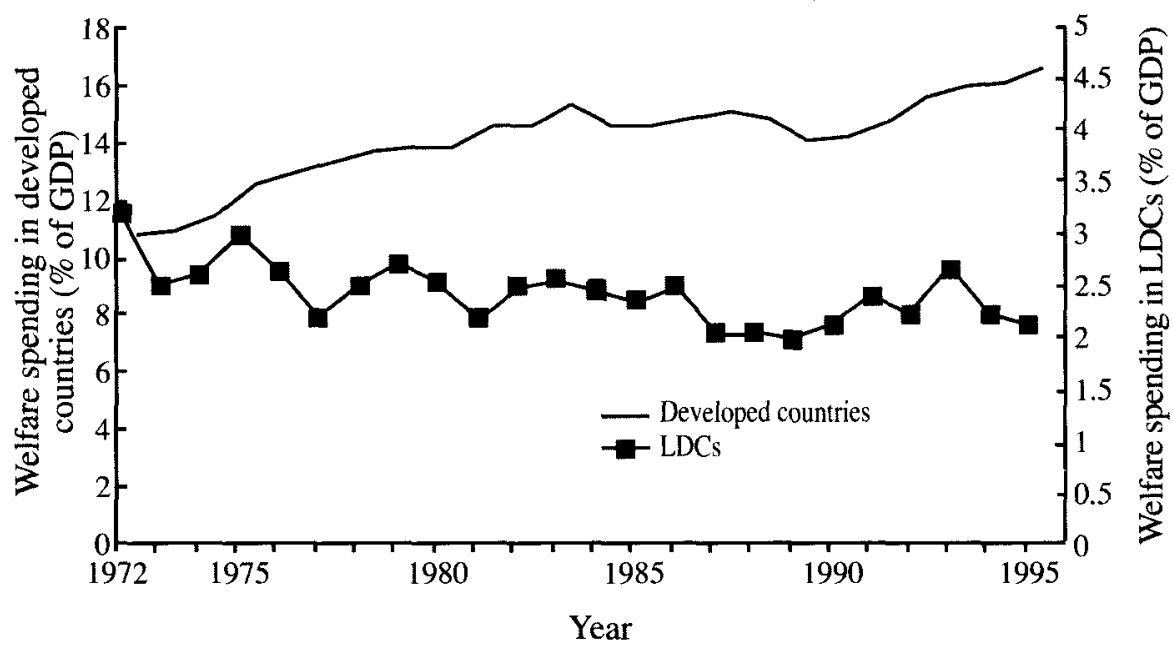

FIGURE 1. The contrast in government welfare spending between developed and developing countries, 1972-95

Sources: IMF, International Finance Statistics and Government Finance Statistics, various years. Notes: Data for the following countries was included in all the figures and regressions. Lessdeveloped countries: Argentina, Bangladesh, Bolivia, Botswana, Brazil, Cameroon, Chile, Colombia, Costa Rica, Cyprus, Dominican Republic, Ecuador, Egypt Arab Rep., El Salvador, Fiji, Ghana, Greece, Guatemala, Guyana, Honduras, India, Indonesia, Iran, Israel, Jordan, Kenya, Korea Rep., Kuwait, Lesotho, Liberia, Malawi, Malaysia, Mali, Mauritius, Mexico, Morocco, Nepal, Nicaragua, Pakistan, Panama, Paraguay, Philippines, Singapore, Sri Lanka, Syria, Tanzania, Thailand, Trinidad and Tobago, Tunisia, Turkey, Uruguay, Venezuela, and Zimbabwe. Developed countries (the fourteen OECD nations analyzed by Garrett 1998): Austria, Belgium, Canada, Denmark, Finland, France, Germany, Italy, Japan, Netherlands, Norway, Sweden, United Kingdom, and United States. The welfare trend was calculated using King et al.'s (2001) multiple imputation model for missing data. According to King et al., most methodologists and statisticians agree that multiple imputation is a "superior approach" to the problem of missing data.

prevent the dismantling of the welfare state, quite unlike labor in the more developed countries.

A long tradition in political science puts labor at the center of studies pertaining to welfare state outcomes. ${ }^{5}$ Focusing primarily on the historical experience of the developed countries of Western Europe, these scholars maintain that the growth of a welfare state depends on a well-organized labor movement. ${ }^{6}$ More recently, the debate has centered on whether the increasing integration of international markets has become the most powerful force affecting the ability of governments to uphold their welfare commitments. Several scholars have convincingly shown that strong labor movements, such as those in European social democracies, can discourage

5. See Korpi 1983; O'Connor and Olsen 1998; Esping-Andersen 1990; Hicks 1999; and Garrett 1998.

6. See, for example, Garrett 1998; Hicks 1999; Korpi 1983; and Esping-Andersen 1990. 
governments from reducing welfare spending during globalization. ${ }^{7}$ I challenge the generalizability of these findings using an analysis of the political power of labor in LDCs. The Stolper-Samuelson theorem implies that the most abundant factors of production will gain from increased openness. In LDCs, low-skilled labor is highly abundant, yet persistent collective-action problems accompanying globalization undermine labor's political clout in LDCs. I assess these two opposing effects by introducing a new indicator of labor power (potential labor power, PLP). My results clearly indicate that the collective-action problems of labor in countries with large pools of low-skilled and surplus workers tend to offset labor's potential political gains from globalization.

This study is the first large- $n$ cross-national time-series study of LDC welfare programs that focuses on globalization and the political strength of labor in LDCs as two of the main forces driving government social spending. Conventional analyses that impose models insensitive to the political and economic conditions prevailing in LDCs have biased our understanding of the sustainability of welfare spending in this era of globalization. I use empirical work based on the politics of social spending in developed countries as a starting point for building a model more suitable for developing countries. ${ }^{8}$ To mitigate the disadvantages of making broad generalizations about many different LDCs, I obtained estimates using panel data (unbalanced) and the fixed-effects method. I find that in response to globalization pressures, governments' commitments to welfare spending ultimately depend on strong labor-market institutions like those that exist in developed countries.

My analysis proceeds as follows. I first evaluate the literature on globalization and social spending in developed countries with an eye toward building a theory of domestic and international determinants of government welfare expenditures in LDCs. I then compare trends in capital flows, trade, and welfare spending in LDCs with those in developed countries. In the third section I provide evidence in support of my primary argument by establishing the premise of a globalization-welfare model specific to LDCs and then testing it by way of panel regressions. In the final section I discuss the implications of the econometric results for LDCs.

\section{Existing Literature on Welfare States in this Era of Globalization}

The literature on the politics of welfare-state spending does not sufficiently explain how or why long-run trends in welfare spending in LDCs differ from those in developed countries. The conventional wisdom is that expanding international markets and prioritizing efficiency and national competitiveness concerns will undermine the welfare state. Geoffrey Garrett and several other theorists, however, 
have refuted such claims, but only for countries within the Organization for Economic Cooperation and Development (OECDs). ${ }^{9}$ Are LDCs similarly defying such doomsday predictions in the age of globalization? Although some scholars, albeit vaguely, do question the sustainability of welfare programs in LDCs, systematic explorations of government social spending in LDCs have yet to be undertaken. $^{10}$

Conventional wisdom suggests that all states, regardless of their partisan compositions and national differences, would embrace neoliberal policies in order to maintain international competitiveness in a globalizing world. ${ }^{11}$ Consequently, the demise of the welfare state is expected for two reasons. First, generous welfare benefits are not regarded as good market-disciplining devices on labor. Both the resulting upward pressures on labor costs and the dampening effects on work incentives are claimed to adversely affect export competitiveness. Second, globalization discourages governments from raising revenue. "Footloose capital," or the capacity to withdraw and shift both productive and financial capital with greater ease, has made it increasingly difficult for governments to generate revenues through taxation. ${ }^{12}$ This "race to the neoliberal bottom" in tax rates is compounded by governments' lowering taxes to compete with other states for international investors and to prevent capital flight. By the same token, state borrowing, which leads to higher debt and interest rates, also deters investment. The last two decades have thus become witness to the reification of Charles Lindblom's "markets as prisons" idea. ${ }^{13}$ With increasing global competition, governments supposedly find it more difficult to protect citizens from market-generated risks and inequalities.

By analyzing fourteen OECD countries, Geoffrey Garrett presents the most recent and convincing challenge to the notion that welfare states are crumbling under these pressures. ${ }^{14}$ Garrett's analysis extends the globalization-welfare debate initiated by Karl Polyani, John Gerard Ruggie, and Peter J. Katzenstein. ${ }^{15}$ He demonstrates that international market exposure actually induces greater government spending on redistribution programs that compensate for market-generated inequalities. Key to Garrett's analysis is the ability of labor-market institutions to effectively negotiate

9. See Garrrett 1998; and Garrett and Mitchell 1996. Others who challenge the conventional wisdom are Hicks 1999; Hicks and Swank 1992; Cameron 1978; and Katzenstein 1995.

10. For more general analyses on LDC welfare states, see, for example, Heredia 1997; Hurrell and Woods 1995; Schmidt 1995; Tang 1996; Esping-Andersen 1996; Mesa-Lago 1994; Usui 1994; Ahmad and Hussain 1991; Midgley 1984; and Wahl 1994.

11. See Drunberg 1998; Strange 1997; Gray 1998; Greider 1998; Cerny 1995; Ruggie 1994; Evans 1997; and Gill 1995.

12. For a critique of this idea, see Swank 1998.

13. Maxfield 1998.

14. Garrett 1998.

15. The theoretical basis for this debate was laid by Karl Polanyi and advanced by John Ruggie with his concept of "embedded liberalism." See Polanyi 1944; and Ruggie 1982. These authors separately conjecture that the state must make a broader commitment to social welfare in order to temper the "pernicious effects" of international markets. See also Cameron 1978; Rodrik 1998; and Katzenstein 1985, who demonstrate that there has been a positive relationship between trade exposure and government social spending throughout much of the twentieth century. 
between government and labor. He convincingly argues that if labor markets are highly centralized and well developed, then labor and government can effectively coordinate economic performance with redistribution policies. He concludes that globalization has in fact strengthened left-labor movements, and, consequently, cross-national partisan differences in the developed world have been sustained.

Several theorists have provided alternative institutional explanations for the resilience of the welfare state in developed countries. ${ }^{16}$ Specifically, Paul Pierson's widely cited study maintains that relatively new cross-class coalitions have resisted the dismantling of the contemporary welfare state. ${ }^{17}$ He rebukes advocates of the conventional thesis for overlooking the crucial importance of the well-developed interest group environment in industrialized nations. Consumers of welfare benefits (such as the elderly and the disabled), he argues, have successfully mobilized to prevent a sharp deceleration of social spending. ${ }^{18}$ Significantly, this research de-emphasizes the role that well-organized labor groups might currently play in the continuation of government welfare spending in developed countries.

Both arguments imply that social spending under globalization depends on liberal democratic organizations and their derivative institutions. Arguably such assets are not readily available for citizens of a majority of nations. In LDCs, those most disadvantaged by globalization do not have the formal democratic means by which to negotiate with governments. ${ }^{19}$ Most developing countries lack both favorable institutional arrangements for establishing cross-class coalitions and strong labor market institutions (as defined by Garrett).

Thus, the situation of contemporary LDC welfare states, where labor is the primary pressure group, remains unexplained. Compared with other societal forces in LDCs, labor groups have historically been the most well-organized (though not in all cases). ${ }^{20}$ Therefore, an LDC model that effectively captures the globalizationwelfare nexus must account for labor's role in the existence of the welfare state. ${ }^{21}$ Such an analysis draws from power resource theories that suggest that the success of welfare states depends on a well-organized labor movement. ${ }^{22}$ The question remains whether labor in LDCs has the same wherewithal to withstand the pressures of globalization that it does in Garrett's sample of fourteen OECD countries.

16. See Hicks 1999; Pierson 1996; and Hicks and Swank 1992.

17. Pierson 1996. See also Clayton and Pontusson 1998, who challenge some of the tenets of this thesis and move forward with a critique of Pierson 1996.

18. Pierson 1996.

19. Statistical data in Keith Jagger's and Ted Robert Gurr's Polity III (1994) on democracy ratings make valid this comparison between developed and developing countries. For an index on democracy for 132 developing countries in 1988, see Hadenius 1992. Note, in particular, the low ratings of LDCs in organizational freedoms and effective and correct elections. For more theoretical discussions on the limitations of democracies in developing countries, see Rueschemeyer et al. 1992; and Crisp 1994.

20. See Midgley 1984; and Schmidt 1995.

21. Unless otherwise specified, "labor" refers to both low-skilled and skilled workers.

22. See O'Connor and Olsen 1998; Esping-Andersen 1990; and Korpi 1983. 


\section{Trade, Capital Flows, and Government Welfare Spending: The Contrast Between Developed and Developing Countries}

From 1972 to 1995, globalization increased in both developed and developing countries, yet trends in government spending for social welfare diverged during this period: spending rose in rich countries and slightly declined in LDCs. The historical relationship between globalization and the welfare state in developed countries makes it all the more intriguing why this same relationship does not seem to be materializing in LDCs. Social-welfare programs are not a new phenomenon in LDCs; they were implemented as early as 1924, beginning with Chile, and have since spread to over seventy developing countries.

Trade and capital flows are two common indicators of globalization. ${ }^{23}$ Trade is measured here as imports plus exports as a percentage of GDP, and capital mobility is represented by the sum of capital inflows and outflows as a percentage of GDP. The concept of the "LDC welfare state" is adopted from Alfred Phaller, Ian Gough, and Goran Therborn and refers to "the use of state power and responsibility towards the ends of protecting citizens against economic adversities and ensuring a certain standard of prosperity to all." ${ }^{24}$ The figures on welfare pertain primarily to central government expenditures on social security and welfare services (as a percentage of GDP). Some provincial and municipal spending is thus not captured.

OECD countries expanded their spending from an average of 12 percent of GDP in 1972 to 16 percent in 1995. Meanwhile, LDCs spent an average of 3.2 percent in 1972-74 and 2.5 percent in 1994-95. Figures 2 and 3 illustrate the striking contrast between these two groups of nations. ${ }^{25}$

The LDC sample in this analysis includes all those for which I could obtain comparable data on welfare spending. The fifty-three countries in the sample are low, middle, and high-income non-OECD countries as categorized in the World Bank's 1997 World Development Indicators. ${ }^{26}$ This data set is regionally diverse, covering twenty Latin American and Caribbean countries, twelve African countries, eight Middle Eastern countries, ten Asian countries, and three European countries. Of these, the majority are low and middle income countries (sixteen and thirty-two, respectively), and five are high-income non-OECD countries. Thus the sample is

23. See Garrett 1998; Garrett and Mitchell 1996; Rodrik 1997b; and Bernauer and Achini 2000.

24. Pfaller et al. 1991.

25. See Figure 1 for the list of countries included and Appendix A for a more detailed description of how trade and gross capital flows are calculated.

26. Although Greece, Turkey, Mexico, and Korea are currently OECD members, they were included in the LDC sample because of the lower income levels that characterized them at the beginning of this study (1970s). To determine whether they were outliers, regressions were run with each country alternatively excluded and then with the group as a whole excluded. The estimates were not affected by their exclusion. 


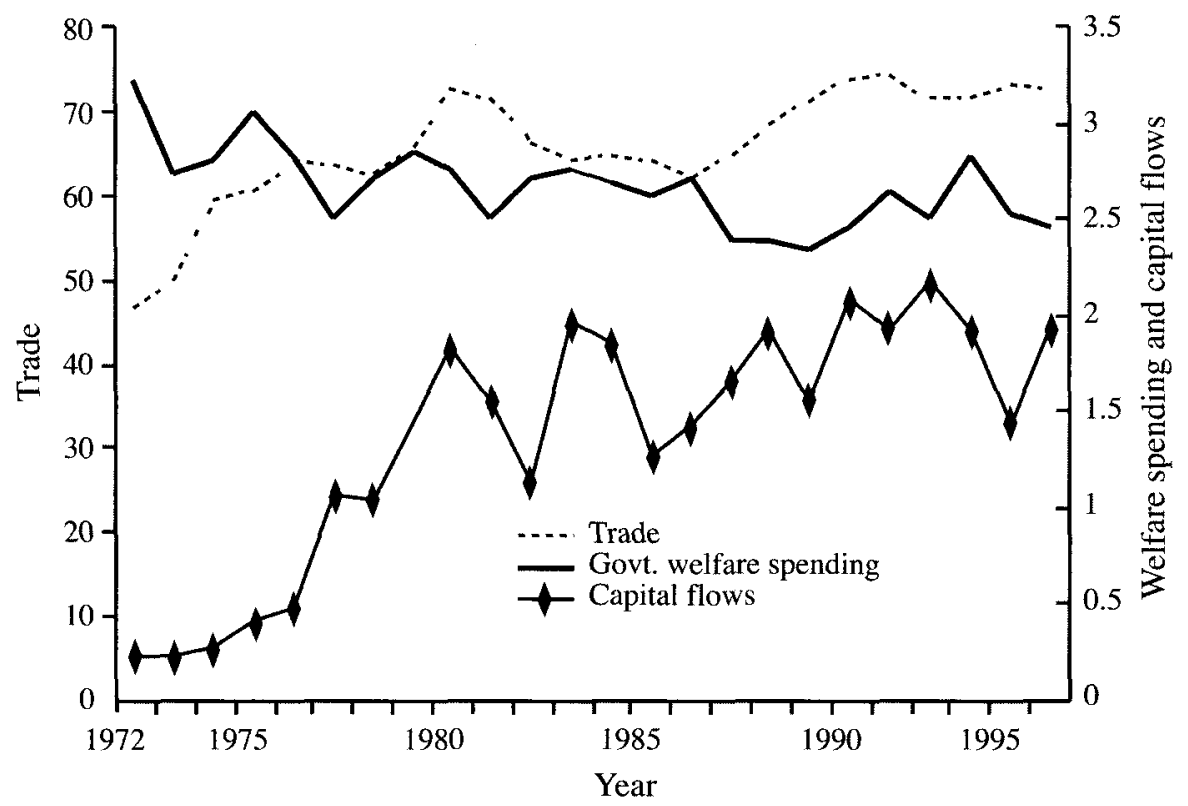

FIGURE 2. Trade, capital flows, and welfare spending in fifty-three LDCs

Sources: IMF, International Finance Statistics and Government Finance Statistics, various years.

biased in the sense that it excludes Eastern European countries ${ }^{27}$ and several newly industrialized countries. Fast-emerging international market participants, such as China and Taiwan, were among those excluded because of the lack of data. ${ }^{28}$

\section{The Theory}

Globalization is likely to adversely affect government commitments to social welfare in nations highly endowed with low-skilled labor. This theory challenges the view that labor in LDCs will experience both economic and political gains with globalization; following such logic, if exposure to international markets is increasing, abundant labor should be in a better political position to demand greater government social-welfare spending. I suggest, however, that labor in LDCs is in a

27. Eastern European countries were intentionally excluded from this data set because their historical circumstances (particularly regarding state social spending) are distinct from the majority of non-OECD developing countries. These countries are not readily comparable to other LDCs because they are undergoing a unique historical experience with respect to their market transitions, have comparatively different functions for the state and welfare, and on average, maintain much higher levels of spending on welfare relative to GDP. Therefore, inclusion of these countries would skew the data and bias the results.

28. It is likely, however, that such an omission creates a more homogenous sample of developing countries, since these missing countries tend to have exceptionally high levels of globalization and would thus skew the data. Compared to the average LDC, integration into the world economy for the NICs has been occurring at an exceptionally rapid pace. See Griffith-Jones and Stallings 1995. 


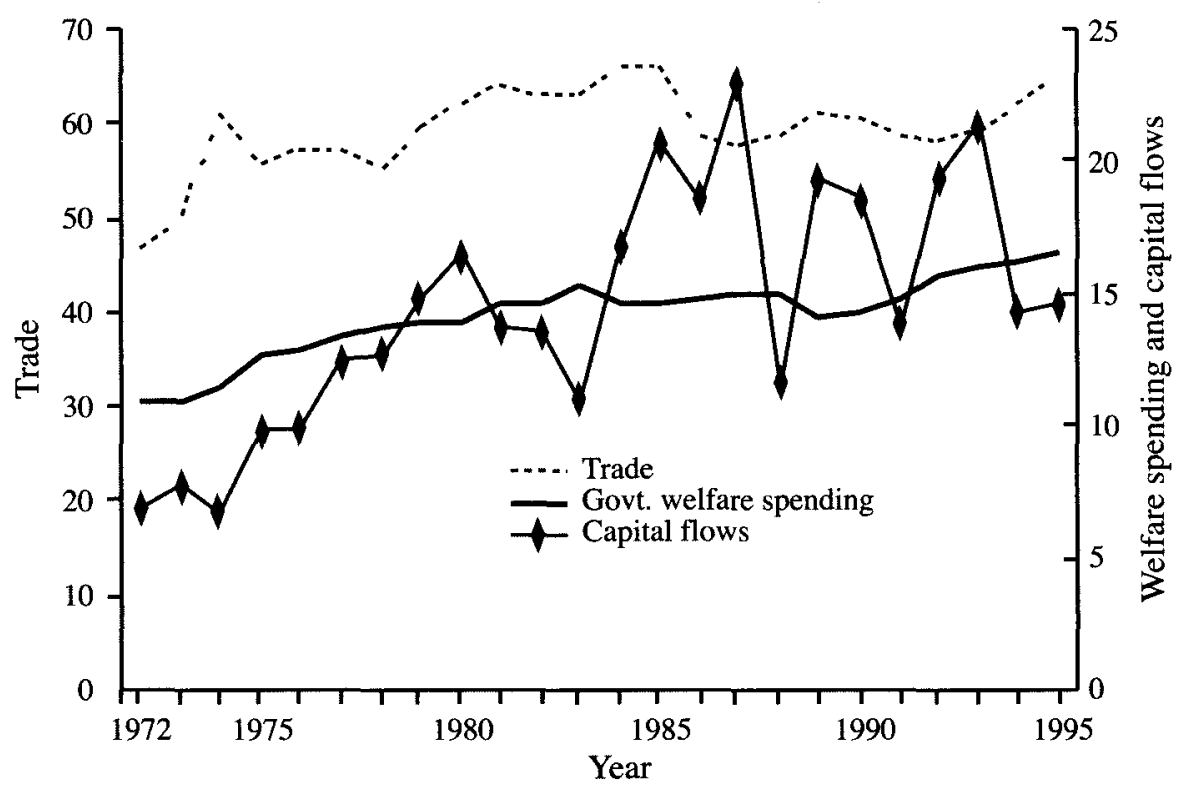

FIGURE 3. Trade, capital flows, and welfare spending in fourteen $O E C D$ countries

Sources: IMF, Government Finance Statistics and Balance of Payments Statistics, various years; World Bank, World Development Indicators, various years.

weak bargaining position because the sizeable population of low-skilled workers faces collective-action problems that are exacerbated by large pools of surplus labor. Labor in LDCs, unlike in developed countries, does not generally have national labor-market institutions that can help mitigate these problems and strengthen workers' bargaining power. Thus globalization in LDCs will lead to less, not more, social-welfare spending.

The theory I propose is based on specific assumptions regarding the different motivations behind welfare spending. First, the theory assumes that workers desire greater welfare benefits, and owners of capital prefer lower welfare spending. Owners' predisposition is based on a preference for paying lower taxes, receiving higher investment returns, and encountering less overall government interference. Second, it assumes that governments are primarily concerned with promoting the aggregate level of economic performance and, at the same time, arbitrating between the political demands of societal groups commanding power resources.

The importance of factor endowments in determining who gains and who loses with globalization stems from the Hecksher-Ohlin model and the related StolperSamuelson theorem. These suggest that with increased exposure to international markets, low-skilled labor in LDCs should experience higher wages and employ- 
ment, whereas in the more developed countries, high-skilled labor and capital should gain. This logic could also be applied to capital flows. Both productive and financial capital flows will increase in nations that are more efficiently utilizing their most abundant factor. Thus, in LDCs rich in low-skilled labor and poor in capital and high-skilled labor, globalization should improve the economic conditions of low-skilled labor.

Ronald Rogowski combines the above theorem with a model of politics to show that owners of locally abundant factors will consequently expand their political power. ${ }^{29}$ His analysis suggests that low-skilled labor in LDCs will have a stronger bargaining position because of the greater wealth that accompanies openness. ${ }^{30}$ Conversely, capitalists and skilled workers will be better able to influence government policies in the more developed countries. Yet the implicit assumption in Rogowski's model that the organizing potential of labor is strong is inappropriate for LDCs. Labor groups in LDCs have serious collective-action problems and, therefore, have difficulty advancing their common political interests, despite the economic gains they might reap from globalization.

Low-skilled workers are initially difficult to mobilize because they have little education, work erratic hours, and a growing percentage of them are women, who, according to the literature, are exceptionally hard to organize. ${ }^{31}$ In addition, this group is large in LDCs and growing with globalization. This situation results in collective-action problems because, according to Mancur Olson, the larger the group, the greater the propensity for the free-rider problem to occur, and the less likely that the collective good (welfare benefits, for instance) will be supplied. ${ }^{32}$

The crux of the problem lies in the existence of the surplus labor population in most LDCs. Large numbers of surplus workers alter the cost-benefit ratio of organizing and for two reasons reduce the incentives for low-skilled labor to mobilize. First, in an era of heightened global competition, large enterprises profit from the existence of surplus labor pools because they help minimize labor costs, are unprotected, and increase flexibility. To participate in this highly competitive environment, low-skilled workers are thus unlikely to unionize. Second, the presence of surplus labor makes it impossible to offer "selective incentives," as Olson suggests, to help labor overcome its collective-action problems. ${ }^{33}$ For example, surplus labor makes it extremely difficult for union organizers to offer secure

29. Rogowski 1989.

30. Note that Rogowski does not make the distinction between skilled and low-skilled labor with respect to factor endowments. This distinction was emphasized by Wood. See Wood 1997, 1995, and 1994; and Wood and Mayer 1998. Wood defines skilled workers as those with more than a basic general education, for example, professional and technical workers, managers, and craftsmen. Wood 1994, 6. Thus, skilled workers are generally employed in high-skilled intensive manufacturing. Low-skilled labor refers to workers who have limited or no education (referring to both Wood's BAS-EDs and NO-EDs, respectively).

31. For more detailed hypotheses on why low-skilled labor groups in LDCs are difficult to organize, see Deyo 1989, chap. 6; Gereffi 1995; Lok 1993; and Ingersen 1984.

32. Olson 1971.

33. Ibid. 
employment for union members. ${ }^{34}$ Because so many low-skilled workers are without work, they focus on gaining employment rather than on lobbying for social-welfare benefits.

Skilled-labor groups in LDCs, on the other hand, are better able to surmount their collective-action problems. These groups are generally smaller in size, less threatened by a surplus labor population, and more likely to lobby for welfare benefits. ${ }^{35}$ In fact, the skilled industries (such as heavy industry and the white-collar professions) have historically been the recruiting grounds for labor organizations in LDCs. Not surprisingly, therefore, skilled-labor groups tend to comprise the bulk of welfare beneficiaries in LDCs. ${ }^{36}$

Given this logic, an increase in the number of skilled workers relative to low-skilled workers would help labor as a whole to overcome its collective-action problems and advance low-skilled workers' political interests, provided that the level of surplus labor is not too high. The higher the ratio of skilled to low-skilled labor and the lower the surplus in a country, the greater the likelihood that labor will form coalitions and be able to defend welfare spending.

In sum, globalization leads to lower social-welfare spending in labor-rich LDCs because low-skilled workers have limited political leverage. In LDCs, labor's political power and interests are the opposite of what existing political and economic theories predict. In most developed countries, however, labor groups have the institutional clout to ensure that they do not lose political power with globalization and can successfully demand compensation in the form of social-welfare spending.

\section{The Evidence}

To test the theory, I first provide comparative data on labor skills and labor surpluses in developed and developing countries. I then present a model of the globalizationwelfare nexus in LDCs and conduct a more thorough empirical test of the theory using multivariate panel regressions.

\section{Increased Global Supply of Goods Produced by Low-Skilled Workers}

Globalization is generating greater competition among countries with similar factor endowments. In several empirical studies, Adrian Wood convincingly shows that nations with large numbers of low-skilled workers follow the principles of comparative advantage and place more emphasis on labor-intensive manufactured

34. Note that while LDCs with state-corporatist systems might offer some of these incentives, it has been argued that the objective is to control and weaken labor. Thus, the reference here is to independent unions.

35. See Mesa-Lago 1994 and 1991; Midgeley 1984; and Esping-Andersen 1996.

36. See Manning 1998; Shafer 1994; and Deyo 1989 and 1991. 
TABLE 1. The growth and share of labor-intensive manufacturing exports

\begin{tabular}{lrr} 
Low income countries & & \\
Primary products & 12.7 & 60.1 \\
Natural-intensive manufacturing & 12.6 & 13.4 \\
Labor-intensive manufacturing & 18.9 & 14.6 \\
Technology-intensive manufacturing & 13.2 & 3.6 \\
$\quad$ Human capital-intensive manufacturing & 14.7 & 2.8 \\
Low-middle-income countries & & \\
Primary products & 9.4 & 56.6 \\
Natural-intensive manufacturing & 7.6 & 4.6 \\
Labor-intensive manufacturing & 14.8 & 20.8 \\
Technology-intensive manufacturing & 21.2 & 11.3 \\
$\quad$ Human capital-intensive manufacturing & 11.6 & 6.0 \\
High-middle-income countries & & \\
Primary products & 9.0 & 49.23 \\
Natural-intensive manufacturing & 18.8 & 7.23 \\
Labor-intensive manufacturing & 10.5 & 13.46 \\
Technology-intensive manufacturing & 13.3 & 15.54 \\
$\quad$ Human capital-intensive manufacturing & 9.8 & 12.00 \\
High-income OECD countries & & \\
Primary products & 8.07 & 23.86 \\
Natural-intensive manufacturing & 10.21 & 4.79 \\
Labor-intensive manufacturing & 8.57 & 9.07 \\
Technology-intensive manufacturing & 12.14 & 35.47 \\
Human capital-intensive manufacturing & 9.50 & 23.43 \\
\hline
\end{tabular}

Source: UN ITC InfoBase: National Trade Performances by Country 1999.

goods. ${ }^{37}$ As Table 1 clearly shows, and in line with the Stolper-Samuelson theorem, labor-intensive exports have grown faster than other exports in countries known to have large pools of low-skilled workers. As I argued earlier, trade in goods and services and in capital flows has driven this growth.

Yet whether the increasing number of low-skilled workers in LDCs relative to skilled workers implies positive political advantages for labor depends on the size of the surplus labor pool. Figure 4 shows that surplus labor in LDCs has indeed declined slightly over time, suggesting that labor power in LDCs may have improved. Yet it cannot be overlooked that by the mid-1990s, the average

37. Wood emphasizes the importance of this distinction between low-skilled and skilled labor. See Wood 1997, 1995, 1994; Wood and Berge 1997. He claims that trade is based on the availability of skills, not capital. Wood defines skilled workers as those with more than a basic general education, for example, professional and technical workers, managers, and craftsmen; Wood 1994, 6. Thus skilled workers are generally employed in high-skilled intensive manufacturing. Low-skilled labor refers to workers who have limited or no education (referring to both Wood's BAS-EDs and NO-EDs, respectively). 


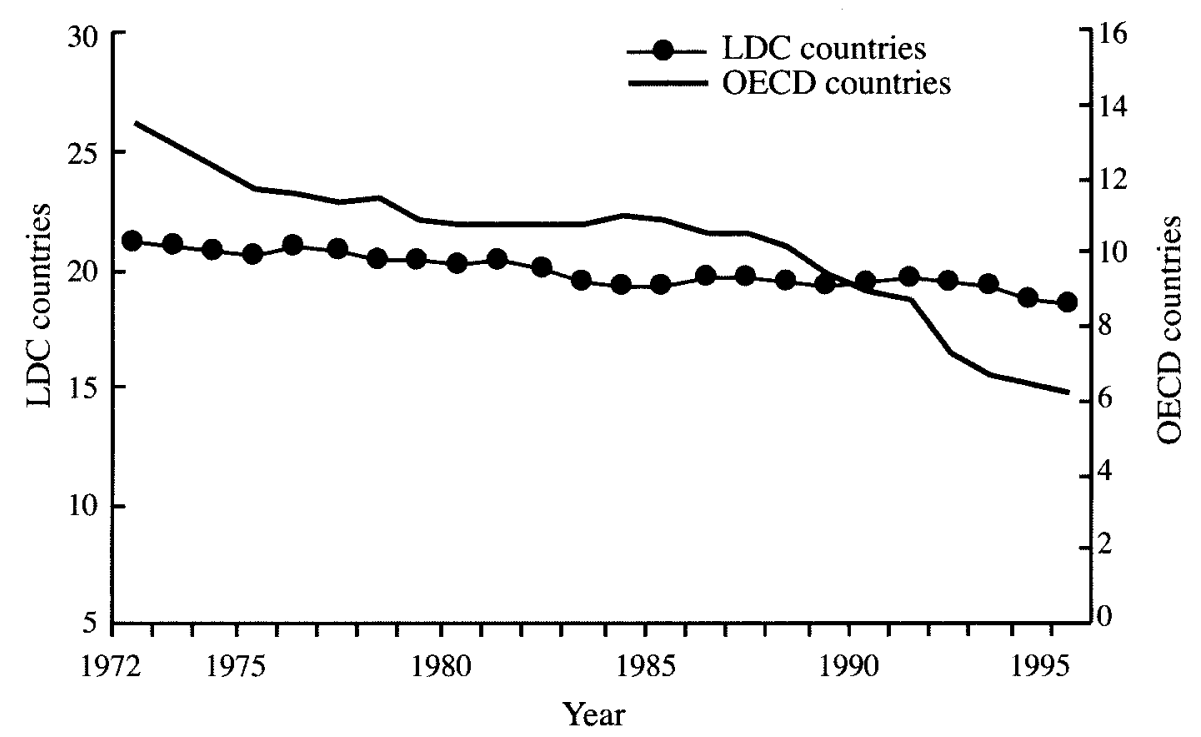

FIGURE 4. Surplus labor in LDCs and developed countries from 1972 to 1995 (as \% of economically active population)

Sources: World Bank 1999, World Development Indicators; and USA. D. Global Education Database, 1999.

Note: Surplus labor is calculated as the (working age population minus students enrolled in secondary education minus students enrolled in 'post-secondary' education) minus (labor force/the working age population). I am grateful to Hayward Alker for helping me derive this measure.

level of surplus labor in LDCs was as high as 19 percent of the working-age population, whereas in OECD countries it was only 6 percent. Moreover, since then surplus labor in LDCs has declined, on average, by only fifteen percentage points. In sharp contrast, surplus labor in the OECD countries Garrett sampled fell by almost 60 percent. A recent UN report confirmed that employment growth has failed to significantly reduce the vast amount of surplus labor that exists in LDCs. ${ }^{38}$

Given that since the 1980s the number of low-skilled workers has been steadily increasing in LDCs and that the surplus labor population is still relatively high, the logic of Olson's theory suggests that labor will be unable to overcome its collectiveaction problems with globalization. An econometric test is needed to more precisely analyze labor's ability to mediate between the forces of globalization and pressures for welfare retrenchment. 


\section{Model Specification}

I assess the LDC globalization-welfare nexus in two stages. First, I develop an LDC model to examine the influence of both domestic- and international-level variables on government welfare spending. To check the robustness of the findings, I reevaluate the globalization results for the globalization-labor variable using alternative indicators of government commitment to welfare. Second, I apply the model to Garrett's sample of OECD countries to assess whether or not the labor power variable drives the different outcomes in welfare spending in LDCs and developed countries. ${ }^{39}$

\section{The LDC Model}

$$
\begin{aligned}
\text { WELF }_{i t}= & \beta_{1} \text { WELF }_{i t-1}+\beta_{2} \text { TRADE }_{i t-1}+\beta_{3} \text { KFLOW }_{i t-1}+\beta_{4} \text { PLP }_{i t} \\
& +\beta_{5} \text { TRADE }_{i t-1} * \text { PLP }_{i t}+\beta_{6} \text { KFLOW }_{i t-1} * \operatorname{PLP}_{i t}+\Sigma\left(\beta_{j} X_{j i t-1}\right) \\
& +\Sigma\left(\beta_{k} \text { COUNTRY }_{k i}\right)+\Sigma\left(\beta_{l} \text { YEAR }_{l t}\right) \mu_{i t}
\end{aligned}
$$

where WELF is the government welfare-spending variable; TRADE and KFLOw, or capital flows, are the globalization variables; and Potential Labor Power (PLP) is the labor power variable. The $\beta$ 's are parameter estimates; $\beta_{1}$ is the coefficient of the lagged rate of welfare spending, incorporated to alleviate problems of serial correlation across error terms; $i$ and $t$ are the country and year of the observations, respectively; and $\mu$ is an error term. $\Sigma X$ represents the vector of control variables. The globalization variables are lagged to account for the period of "adjustments." Also, note that logarithms are taken of all the primary variables. ${ }^{41}$ This type of relationship assumes the property of constant elasticities between the variables. (For a detailed description of all the variables, see Appendix A.)

Like Rodrik and Garrett, I use pooling cross-section and time-series data to estimate the model. ${ }^{42}$ This procedure has two benefits. First, the use of the fixed-effects model allows me to control for unobservable country-specific differences, eliminating much of the omitted variable bias of cross-section data. ${ }^{43}$ Second, I can assess important changes that have occurred in a country over time. The use

39. Garrett 1998 .

40. It is theoretically more sensible to anticipate a lagged effect because international market occurrences take time to affect policy outcomes. See, for example, Rodrik 1997b, who uses lagged measures of openness.

41. Because there is very little dispersion in the urbanization and democracy variables, these values have not been logged.

42. See Rodrik 1997b and 1998; and Garrett 1998.

43. The country-specific fixed effects most relevant to this model are culture and history. Informal systems of support for the elderly (such as extended families) are common methods of providing social security in many parts of Africa and Asia. See World Bank Policy Research Report 1994. Such variables are more significant in some countries than in others. Fixed effects allow us to control for the influence of such idiosyncratic differences between countries without our having to model them explicitly. 
of panel data (unbalanced) ultimately combines the benefits of an increased number of observations with the ability to eliminate country-specific fixed effects.

To disentangle the causal relationship between the globalization variables and PLP I rely on a two-stage least-squares estimate for the statistical analysis. Recall that globalization is likely to further enhance collective-action problems in LDCs by adding larger numbers of low-skilled workers to the work force. The conventional method for coping with this endogeneity issue and mitigating bias of the regression estimates is to use the instrumental variable approach; however, the difficulty is to find outside data (or instruments) that are not correlated with the error of the equation yet highly correlated with the explanatory variables. Therefore, instead of using conventional variables as instruments in this model, I employ the Lewbel procedure of using higher moments of the labor power variable as the instrument. ${ }^{44}$

\section{The Variables}

Dependent variable: Social security and welfare. Most globalization studies have focused on total government spending, rather than welfare spending, as the dependent variable, but doing so can be misleading. ${ }^{45}$ Central government spending (or, according to Rodrik, government consumption ${ }^{46}$ ) is a poor indicator of actual welfare outcomes or government commitment to welfare. Indeed, since total government spending includes a broad range of items-such as defense and nondefense spending, capital and current spending, industrial subsidies, and wages and salaries - it can no doubt increase without welfare's share going up. Rather than cushioning market dislocations, higher proportions of the government budget may be allocated toward funding more "competitive" ventures 47 or national security projects $^{48}$. The estimated covariance between total government spending and spending on social security and welfare in LDCs is close to zero (at a mere -0.00004; see Appendix B).

The more narrow variable used here more precisely captures welfare effort. The ratio of social spending to GDP is a direct indicator of the amount of national resources a country has committed to social welfare in relation to its total resources. Thus investigating government social security and welfare spending is one sure method of assessing government priorities in the era of globalization.

Nonetheless, one caveat might be that measuring welfare-state commitments in relation to GDP, while assuring compatibility across countries, could also be

44. Lewbel 1997.

45. A few scholars take a brief look at social insurance and welfare spending as the variable to be explained. See, for example, Bernauer and Achini 2000; Rodrik 1997b; and Garrett 1998. However, most IPE scholars-including those just mentioned-use government spending as their central dependent variable.

46. Rodrik 1998.

47. Drunberg 1998 suggests that with globalization, public authorities in LDCs have greater incentives to help firms compete internationally by raising industrial subsidies.

48. Looney 1993. 
misleading. Rapid GDP growth could cause the indicator to shift downward. As a check against this possibility, welfare spending as a share of total government spending and social-welfare spending per capita are used as alternative dependent variables. $^{49}$

\section{Primary causal variables: The interaction of economic globalization and po-} tential labor power in LDCs. I use both capital and trade flows to operationalize globalization in order to replicate the most sophisticated empirical works on globalization and welfare state expansionism, ${ }^{50}$ as well as to incorporate the two primary international forces said to affect contemporary social policies ${ }^{51}$. Several empirical studies have declared LDCs as de facto open in capital and trade markets. ${ }^{52}$ I incorporate the conventional measure of openness, exports plus imports relative to GDP, in this LDC model. I measure capital mobility in LDCs using capital inflows plus outflows, in contrast to Garrett and Rodrik's use of capital controls to measure capital mobility in OECD countries. Gross flows are an exogenously-determined measure of capital mobility, whereas capital controls are not, and annual data are available. ${ }^{53}$

At the heart of my theory is the idea that the effect of globalization on welfare spending depends on labor's influence in the political economy in LDCs. The most common indicator of this is unionization rates. ${ }^{54}$ However, a fundamental problem with this indicator is that, unlike the situation in developed countries, union density (percentage of the working population who are unionized) is not comparable across LDCs. Many LDC governments mandate compulsory membership in corporatist unions and impose constraints on labor's demand making, leadership, and internal governance. ${ }^{55}$ China, for example, has the highest union density in the developing world, yet labor has very little bargaining power. ${ }^{56}$ In general, unionization rates exaggerate labor's independent political strength in LDCs. ${ }^{57}$ Moreover, there are no standardized cross-country time-series measures for many LDCs. PLP, an indirect measure of labor power, captures the dynamic nature of labor's influence and is

49. For another example of a study that uses per capita social expenditures as a third dependent variable, see Kaufman and Segura-Ubiergo 2001.

50. See Garrett 1998; and Garrett and Mitchell 1996.

51. Rodrik argues that capital mobility and trade have differential effects on social policies. See Rodrik $1997 \mathrm{~b}$ and 1998.

52. See Montiel 1994; Amirahmadi and Wu 1993; Dean 1995; and Mamingi 1997.

53. For a discussion on gross capital flows as one of the four different ways of measuring capital mobility, and their pros and cons, see Montiel 1994; and Agenor and Montiel 1996. For other economists implementing this proxy of capital flows, see Taylor and Sarno 1997; and Chuhan, Claessens, and Mamingi 1993.

54. See Devarajan et al. 1997; Galenson 1962.

55. Collier and Collier 1991.

56. Chan and Senser 1997.

57. See, for example, Valenzuela 1989, 449; and Banuri and Amadeo 1991, 175. McGuire 1997 adds that unreliability of union data can result in huge discrepancies in existing cross-country compilations of union-density estimates. 


\begin{tabular}{|c|c|c|}
\hline & High & Low \\
\hline & Skilled labor/low-skilled labor & Skilled labor/low-skilled labor \\
\hline High & $(+)$ & $(-)$ \\
\hline Surplus labor & $\begin{array}{l}\text { Moderate PLP } \\
\text { (Chile, Venezuela, Egypt) }\end{array}$ & $\begin{array}{l}\text { Low PLP } \\
\text { (Guatemala, Pakistan, Honduras) }\end{array}$ \\
\hline Low & $(+)$ & $(+)$ \\
\hline Surplus labor & $\begin{array}{l}\text { High PLP } \\
\text { (Singapore, Korea, Turkey) }\end{array}$ & $\begin{array}{l}\text { Moderate PLP } \\
\text { (Uruguay, Indonesia) }\end{array}$ \\
\hline
\end{tabular}

\section{FIGURE 5. Labor power in LDCs}

Note: These are averaged low and high PLP values, ranked according to the 25th and 75 th percentiles, respectively. Signs in parentheses represent the expected direction of the relationship of potential labor power to welfare.

comparable across LDCs. Assuming there is always some surplus labor and some low-skilled labor, PLP is measured here by the following ratio:

$$
\begin{aligned}
\text { PLP } & =\left(\frac{\text { Number of skilled workers }}{\text { Number of low-skilled workers }}\right) \\
& \times\left(\frac{1}{\text { Surplus labor as \% of working-age population }}\right)
\end{aligned}
$$

PLP decreases as the number of low-skilled workers increases relative to skilled workers, and as surplus labor expands. To the extent that the surplus labor pool shrinks and labor markets become tighter, PLP increasingly depends on the ratio of skilled to low-skilled workers.

This assessment of PLP is limited to the manufacturing sector, since data are not available for most countries outside this sector. Significantly, however, research has shown that most labor-organizing activities occur in this sector. Figure 5 gives examples of how countries are ranked on the two components of PLP. Table 2 shows PLP values in countries selected from the larger sample. Country scores above and below the mean represent "high" and "low" values for skill levels and surplus labor.

The advantage of using this proxy is that it can capture variations in labor strength irrespective of the type of state-labor relations. It abstracts from the historical complexities behind the political relationship between LDC governments and labor, a relationship that ranges widely from state control of labor or corporatism (such as in Brazil, Mexico, Egypt, Ghana, and Tanzania), state repression of labor (such as in Korea, Zambia, Taiwan, and Singapore), to relative autonomy of labor (such as 
TABLE 2. Country skill ratios and percentages of surplus labor

\begin{tabular}{|c|c|c|c|c|c|}
\hline \multirow[b]{2}{*}{ Country } & \multicolumn{2}{|c|}{$\begin{array}{l}\text { Skilled labor/low- } \\
\text { skilled labor }\end{array}$} & \multicolumn{2}{|c|}{ Surplus labor } & \multirow[b]{2}{*}{ Total PLP } \\
\hline & High & Low & High & Low & \\
\hline Singapore & 1.0 & & & 0.17 & 6 \\
\hline Korea & 0.59 & & & 0.14 & 4 \\
\hline Turkey & 0.42 & & & 0.15 & 2.8 \\
\hline Venezuela & 0.36 & & 0.28 & & 1.3 \\
\hline Chile & 0.36 & & 0.31 & & 1.2 \\
\hline Egypt & 0.35 & & 0.25 & & 1.4 \\
\hline Uruguay & & 0.28 & & 0.19 & 1.5 \\
\hline Indonesia & & 0.24 & & 0.19 & 1.3 \\
\hline Pakistan & & 0.29 & 0.28 & & 1.0 \\
\hline Guatemala & & 0.28 & 0.30 & & 0.9 \\
\hline Honduras & & 0.11 & 0.26 & & 0.4 \\
\hline
\end{tabular}

Notes: The mean value for skilled labor/low-skilled labor is 0.30 . The mean value for percentage of surplus labor is 0.20 .

in India and Nigeria ${ }^{58}$ ). PLP thus provides an indication of labor's underlying capacity to form alliances and influence government fiscal decisions in both state corporatist and noncorporatist systems. Appendix C shows that PLP aligns well with other qualitative rankings of labor power that have been applied to a few select LDCs.

It is also important that the labor power indicator can capture changes over time. For example, a close look at the data shows that PLP in South Korea has moved successfully from the low PLP quadrant to the high PLP quadrant in Figure 5. This indicator should nevertheless be applied with caution. Significant externalities (such as highly repressive regimes) may undermine labor's actual political strength. Singapore is a good case in point.

The primary explanatory variables are the interactive effects of globalization and labor power. These interactive variables, by design, replicate Garrett's model of the relationship between globalization and spending in the developed economies. ${ }^{59}$ Both trade and capital mobility are combined with PLP in order to assess labor's ability to moderate the relationship between globalization and welfare spending in

58. This refers mainly to the relatively independent and effective labor movement in Nigeria during the 1970 s and early 1980 s, headed by the Nigeria Labour Congress (NLC). For details, see Van Hear 1988.

59. Garrett 1998. 
LDCs. If the interactive effects are negative, then it can be determined that the combined effects of weak labor and of increased exposure to higher levels of trade and capital flows result in lower government welfare commitments.

Control variables. Several control variables will help isolate this main relationship and check for other influences on welfare spending. Given that most nations in this sample are considerably underdeveloped, supplementary political and economic variables are included in order to tailor the model to the LDC cases. ${ }^{60} \mathrm{LDC}$ welfare spending is expected to increase with the number of young and elderly dependents, ${ }^{61}$ the level of urbanization, ${ }^{62}$ both GDP per capita and growth, ${ }^{63}$ low debt, lower levels of privatization, ${ }^{64}$ and democracy, ${ }^{65}$ which are the control variables used in this analysis. Unemployment figures, frequently linked to higher welfare spending in developed countries, are excluded because of the unreliability of such figures in underdeveloped nations. ${ }^{66}$

All of the control variables are lagged to ensure that the direction of causality occurs from the exogenous variables to the dependent variable.

\section{The Results}

Equation (1) was estimated for fifty-three LDCs, from the years 1972 through 1995, using the fixed-effects procedure. To summarize the results, LDC welfare spending was quite sensitive to variations in international-level variables. Most significantly, interaction effects of PLP and globalization were highly significant and negative in a model specific to LDCs. When all relevant domestic variables were controlled for, globalization combined with weak labor power has clearly had an adverse effect on welfare spending in LDCs. Conversely, the interactive globalization/PLP variable had a positive impact on spending when applied to Garrett's sample of OECD countries.

The LDC globalization/welfare model. Table 3 reports the results conditioned on both international and domestic effects. I conducted numerous tests to confirm

60. Statistical tests determined that significant multicolinearity did not exist between the control variables.

61. See World Bank Policy Research Report 1994; Esping-Andersen 1990; Tang 1996; and Schmidt 1995.

62. Tang 1996.

63. See Brown and Hunter 1999; Usui 1994, Rodrik 1996; and Tang 1996.

64. Privatization can potentially affect state budgets in multiple ways. However, for the purposes of clarity and the goals of this article, the focus will be on the revenue effects (either positive or negative) of privatizing state-owned enterprises (SOE).

65. Brown and Hunter 1999; Eichengreen 1996; and Hicks and Swank 1992.

66. Agenor and Montiel 1996. 
TABLE 3. Fixed-effects regression estimates: The relationship between globalization and welfare spending in LDCs

\begin{tabular}{|c|c|c|c|}
\hline \multirow[b]{2}{*}{ Independent variable } & \multirow{2}{*}{$\begin{array}{c}\text { Model l } \\
\begin{array}{c}\text { Dependent variable: } \\
\text { welfare as \% of } \\
G D P\end{array}\end{array}$} & \multirow{2}{*}{$\begin{array}{c}\text { Model } 2 \\
\begin{array}{c}\text { Dependent variable: } \\
\text { welfare as \% of } \\
\text { total gov. spending }\end{array}\end{array}$} & \multirow{2}{*}{$\begin{array}{c}\text { Model } 3 \\
\begin{array}{c}\text { Dependent variable } \\
\text { per capita welfare } \\
\text { expenditures }\end{array}\end{array}$} \\
\hline & & & \\
\hline Lagged dependent variable & $\begin{array}{l}0.649 * * * \\
(0.065)\end{array}$ & $\begin{array}{l}0.805^{* * *} \\
(0.049)\end{array}$ & $\begin{array}{l}0.704^{* * *} \\
(0.063)\end{array}$ \\
\hline TRADE * PLP (interactive variable) & $\begin{array}{c}-0.163^{*} \\
(0.099)\end{array}$ & $\begin{array}{c}-0.159^{*} \\
(0.097)\end{array}$ & $\begin{array}{c}-0.160^{*} \\
(0.098)\end{array}$ \\
\hline KFLOW * PLP (interactive variable) & $\begin{array}{c}-0.053 * \\
(0.032)\end{array}$ & $\begin{array}{c}-0.040^{* *} \\
(0.019)\end{array}$ & $\begin{array}{c}-0.051^{* *} \\
(0.026)\end{array}$ \\
\hline Potential labor power (PLP) & $\begin{array}{c}1.31^{* *} \\
(0.509)\end{array}$ & $\begin{array}{c}1.28^{* *} \\
(0.570)\end{array}$ & $\begin{array}{c}1.16^{* *} \\
(0.571)\end{array}$ \\
\hline KFLOW & $\begin{array}{c}0.274^{*} \\
(0.157)\end{array}$ & & \\
\hline TRADE & $\begin{array}{c}0.787 \\
(0.484)\end{array}$ & & $\begin{array}{l}0.150^{* * *} \\
(0.067)\end{array}$ \\
\hline DEMOC & $\begin{array}{l}0.023^{* *} \\
(0.011)\end{array}$ & $\begin{array}{c}0.039 \\
(0.031)\end{array}$ & $\begin{array}{l}0.017^{* *} \\
(0.008)\end{array}$ \\
\hline Urbanization & $\begin{array}{c}-0.005 \\
(0.006)\end{array}$ & $\begin{array}{c}0.001 \\
(0.004)\end{array}$ & $\begin{array}{c}0.007 \\
(0.005)\end{array}$ \\
\hline Growth & $\begin{array}{c}0.489 \\
(0.820)\end{array}$ & & $\begin{array}{l}1.76 \\
(1.08)\end{array}$ \\
\hline GDP per capita & & & $\begin{array}{l}0.0004 * * * \\
(0.0008)\end{array}$ \\
\hline$N$ & 794 & 820 & 768 \\
\hline AIC (smaller is better) & 1.14 & 1.75 & 0.956 \\
\hline BIC (smaller is better) & -3992 & -3675 & -3973 \\
\hline Adjusted $R^{2}$ & .930 & .897 & .973 \\
\hline
\end{tabular}

Notes: Standard errors, corrected for general forms of heteroskedasticity, are in parentheses. Estimates in italics represent the fit statistics.

$$
\begin{aligned}
& * * * p<.01 . \\
& * * p<.05 \\
& { }^{*} p<.10 .
\end{aligned}
$$

the stability of the results. ${ }^{67}$ To check for robustness, I reestimate Model (1) using different dependent variables: welfare as a percentage of total government spending and per capita welfare spending, Models (2) and (3) respectively. After testing the baseline regressions containing all of the predictors under consideration, I reesti-

67. These results are robust to several different estimation techniques. First, results running the regressions with and without missing data, based on the multiple interpolation technique in King et al. 2001 , had minimal effect on the key variables. Varying the lag structure also had little impact on the results. 
mated the models by dropping one insignificant variable at a time. ${ }^{68}$ If the fit statistics improved and the null restriction could not be rejected using the $F$ test, I permanently dropped the predictor from the model. ${ }^{69}$ I placed the greatest weight on the models reported below because they had the best fit overall, and the results are likely to be less biased. The $F$ test (not shown here) confirmed that the final model was better than the full model.

All the measures except capital and trade flows had the anticipated signs. According to Model (1), uninteracted effects of capital flows tend to increase welfare spending, supporting the arguments of recent proponents of globalization who challenge the conventional wisdom that international market exposure leads to higher social spending. ${ }^{70}$ Similarly, increasing trade openness had a positive effect on welfare spending per capita. However, the direct effect of potential labor power (when trade and capital flows are zero) was associated with higher levels of welfare in all three models, strongly supporting power resource theories and indicating that some proxy of labor institutions should be taken into account. These results call into question studies that altogether exclude political institutional variables in their investigations of the domestic effects of international market integration. ${ }^{71}$

Most relevant to the purposes of this analysis is that social spending responds negatively to the combined effects of globalization and PLP. Table 3 reveals that although potential labor power has had a positive and independent effect on welfare spending, it has been ineffective in doing so when combined with international market pressures. The negative coefficients of the globalization interactive terms confirm that LDC welfare spending is indeed a function of high levels of exposure to global market activity and relatively weak labor power. These results cast doubt on previous analyses of LDC welfare spending that have focused on domestic variables and downplayed the importance of international-level variables in their analyses. $^{72}$

The pattern of coefficients for the globalization/labor power interactive variables was consistent across the three models, suggesting that these findings are quite robust. Once the appropriate control variables are used, the trade/labor power and capital flows/labor power interactions are negative and significant at the 90 percent level and above.

68. The privatization variable could not be included in the full model because this data was severely limited. Regressions including this variable were run separately using five-year averages. The coefficient for privatization did not come out as significant.

69. More specifically, in addition to comparing adjusted $R$ squares, smaller values of Akaike's Information Criterion (AIC) and of Bayesian Information Criterion (BIC) indicate better fits of the covariance structure. In addition, we can test whether the reduced parameters significantly improve the model using the $F$ test. See, for example, Intriligator, Bodkin, and Hsiao 1996, 107.

70. Since the model includes interactive effects, the more precise interpretation is that the effect of capital flows is positive when labor power is zero.

71. See Rodrik 1997a and 1998; and Cameron 1978.

72. See, for example, Schmidt 1995; Tang 1996; Midgley 1984; Wahl 1994; and Atkinson and Hills 1991. 
TABLE 4. Elasticity of welfare spending with respect to labor power

\begin{tabular}{lccc}
\hline Globalization & $\begin{array}{c}\text { Level of trade } \\
\text { (as \% of GDP) }\end{array}$ & $\begin{array}{c}\text { Level of capital flows } \\
\text { (as \% of GDP) }\end{array}$ & $\begin{array}{c}\text { Elasticity of PLP on } \\
\text { welfare spending }\end{array}$ \\
\hline Low & $14 \%$ & $1 \%$ & $1.3 \%$ \\
Medium & $68 \%$ & $11 \%$ & $1.2 \%$ \\
High & $122 \%$ & $21 \%$ & $1.1 \%$ \\
\hline
\end{tabular}

The effect of labor power on welfare spending decreases as exposure to international markets increases; the best way to understand this at various levels of globalization is to refer back to Equation (1). Using Model (1) as an example, the estimated equation has the form

$$
\begin{aligned}
\text { WELF }= & 0.649 \mathrm{WELF}(\text { lagged }) \\
& +1.31 \mathrm{PLP}-0.163 \mathrm{TRADE}_{i t-1} * \text { PLP }-0.053 \mathrm{KFLOW}_{i t-1} * \text { PLP } \\
& +0.274 \mathrm{KFLOW}^{+0.023 \mathrm{DEMOC}}
\end{aligned}
$$

The effect of PLP on welfare, $\partial \mathrm{wELF} / \partial \mathrm{PLP}=\beta_{4}+\beta_{5} \mathrm{TRADE}_{i t-1}+\beta_{6} \mathrm{KFLOW}_{i t-1}$, depends on the levels of trade and capital flows.

$$
\partial \mathrm{WELF} / \partial \mathrm{PLP}=1.31-0.163 \mathrm{TRADE}_{i t-1}-0.053 \mathrm{KFLOW}_{i t-1}
$$

We can see the declining impact of labor power if we segregate the data into three sets, having low, medium, and high values of globalization, and then compute the effect of PLP on welfare for each set. ${ }^{73}$ See Table 4 for estimates of the effects of PLP on welfare spending at different levels of globalization (based on Equation [3]).

Thus the effects of potential labor power on welfare depend on the level of globalization and exhibit diminishing returns. A 1 percent increase in labor power at low levels of openness leads to a 1.3 percent increase in welfare spending. Its impact on spending falls to 1.2 percent at median levels of globalization and even lower, to 1.1 percent, at high levels. The data thus supports the existence of a relationship between globalization, potential labor power, and welfare spending.

The findings regarding the impact of the labor power and democracy variables reveal the importance of domestic political variables, while controlling for international effects. Results on democracy were robust and had a positive, independent effect on welfare in both Models (1) and (3). This study is consistent with many

73. The classification of "high" and "low" is based on LDC trade and capital flow values one standard deviation above and below the mean, respectively. The medium value is represented by the mean. 
analyses arguing that the more democratic a nation is, the more responsive the government will be to social well-being. ${ }^{74}$ It is certainly more likely that institutions (autonomous unions, for example) will arise to solve the collective-action problems of labor in democratic LDCs than in authoritarian ones.

The $F$ test revealed that year effects were significant in two out of the three models of welfare spending-Models (1) and (3). This suggests that, overall, global shocks and recessions have some effect on social spending in nations that spend a relatively small percentage of their GDP on welfare. The mixed results on GDP per capita and growth were, at first, surprising. Based on existing literature, it was expected that these variables would be positive and robust across dependent variables. However, on closer inspection of the data, many of the wealthier countries, such as Singapore and Korea, exhibit some of the lowest levels of spending in the sample. Coefficients on several of the remaining control variables (urbanization, age dependency, debt, and privatization variables) were also insignificant. $^{75}$

Finally, the $F$ test allows us to reject the null hypothesis that country differences are not important. This suggests that country-specific differences persist over time. ${ }^{76}$ Yet it is rather telling that even though historical differences account for much of the variations in welfare expenditures, the globalization and labor variables still maintain high statistical significance. Additionally, jack-knife diagnostics reveal that the results were not sensitive to outliers. ${ }^{77}$ The remaining impacts of globalization and labor power can, therefore, be regarded with confidence.

To summarize, the data on LDCs support the conventional wisdom and refute the revisionist perspective. The combined effects of globalization and weaker labor power in LDCs dampen welfare spending. As predicted, their product terms are negative and significant in developing economies. The positive and significant coefficient of democracy in models 1 and 3 adds evidence that regime type is another important political determinant of welfare spending in LDCs.

The comparison between LDCs and OECD countries. Estimating a globalization-welfare model for OECD countries emphasizes the importance of differences in overall labor strength. Findings in this section confirm that workers in the more developed countries, unlike their counterparts in the developing world, are strong enough politically to encourage welfare-state expansionism alongside globalization.

74. See Lake and Baum forthcoming; Brown and Hunter 1999; Atkinson and Hills 1991; and Hicks and Swank 1992.

75. It was rather surprising that the debt variable was not significant. See, for example, Brown and Hunter 1999. Also note that data on debt and age dependency was sparse and involved some interpolation. Thus the coefficients of these variables must be interpreted with caution. The insignificant coefficient on urbanization also seems counterintuitive and stands contrary to the positive and significant effects found by Tang 1996. Results from this model suggest that in the event of rapid urbanization, other political and economic variables outweigh its effect on government welfare spending.

76. Refer to footnote 43 .

77. This method involves reestimating the regression fifty-three times, leaving out one of the countries each time. 
This contrast between the two sets of countries is observed by adopting Garrett's ${ }^{78}$ globalization-welfare model for OECD nations and substituting the PLP variable for his labor variable, and then comparing the results with the LDCs. These final regressions have two important implications. First, since the results using the PLP variable in OECD countries are similar to Garrett's results using his indicator of left-labor power (LLP) in the developed countries, these regressions considerably increase our confidence in the reliability of the PLP variable. ${ }^{79}$ Second, a positive coefficient for the globalization-labor interactive variables confirms the disparity in bargaining power held by labor in the two sets of countries. These findings confirm that the contrasting effects of globalization on welfare states in developed and developing countries are rooted in overall differences in labor power.

It is expected that the interactive globalization-PLP variable will be positive in developed countries because richer nations not only face relatively less severe collective-action problems but also have institutions in place to help surmount them. ${ }^{80}$ Surplus labor problems are simply not as acute in the more developed countries. Labor markets in these countries tend to be much tighter. In addition, the proportion of low-skilled workers in OECD countries has been steadily declining (see Figure 4), suggesting that in these countries labor can more easily overcome its collective-action problems. Finally, these are countries with long-standing liberal democratic traditions. Other welfare beneficiaries (such as the elderly and the disabled) can also form strong interest groups and make it increasingly difficult for the government to roll back welfare spending.

Table 5 reports Garrett's findings on the determinants of OECD income transfers alongside the new estimations substituting the PLP variable for his measure of LLP. ${ }^{81}$ The globalization variables are not necessarily lagged in Garrett's model because his more direct measure of labor power does not call for a time lapse between globalization and changes in LLP. It is reasonable to assume that the effects of the LLP-globalization interaction variables on welfare can occur within the same year. Additional control variables used in Garrett's analysis are GDP growth, proportion of the population over sixty-five years old (ELDERLY), and unemployment. ${ }^{82}$

This final set of regressions appreciably strengthens the conclusions I present here. Contrary to the findings for LDCs, the product terms of globalization and PLPtend to be positive in nations exporting relatively more skill-intensive goods. ${ }^{83}$ As predicted, workers in OECD countries do not face the same collective-action

78. Garrett 1998.

79. See Campbell's (1988) tests for evaluating the validity of variables measuring a concept.

80. Garrett 1998, 8-9.

81. Garrett captures labor power in the developed world by constructing a composite measure for the political power of the left and the strength of national labor market institutions (labor encompassment). Note that Garrett's results for income transfers are reported, instead of his primary dependent variable, government spending. Government income transfers is a better match for social security and welfare spending used in this analysis.

82. Interestingly, GDP growth was not significant in any of the LDC models.

83. Both the globalization variables (trade*left-labor power and capital mobility*left-labor power) were positive and significant in Garrett's central model of total government spending. 
TABLE 5. The effects of globalization on welfare spending in OECD countries

Dependent variable: Social security and welfare

\begin{tabular}{|c|c|c|}
\hline \multirow{2}{*}{ Independent variable } & \\
\hline & Results using left-labor index ${ }^{\mathbf{a}}$ & Results using PLP \\
\hline Lagged dependent variable & $\begin{array}{l}0.86^{* * *} \\
(0.03)\end{array}$ & $\begin{array}{l}0.599^{* * *} \\
(0.04)\end{array}$ \\
\hline TRADE $*$ LLP & $\begin{array}{c}0.007 \\
(0.0019)\end{array}$ & \\
\hline TRADE $*$ PLP (interactive variable) & & $\begin{array}{r}-0.036 \\
(0.072)\end{array}$ \\
\hline KFLOW $*$ LLP & $\begin{array}{l}0.066^{* *} \\
(0.027)\end{array}$ & \\
\hline KFLOW $*$ PLP (interactive variable) & & $\begin{array}{l}0.232^{* *} \\
(0.115)\end{array}$ \\
\hline KFLOW & $\begin{array}{l}-0.19 \\
(0.15)\end{array}$ & $\begin{array}{c}0.002 \\
(0.013)\end{array}$ \\
\hline TRADE & $\begin{array}{c}-0.0084 \\
(0.0123)\end{array}$ & $\begin{array}{l}-0.132 * * * \\
(0.037)\end{array}$ \\
\hline GDP growth & $\begin{array}{l}-0.168^{* *} \\
(0.014)\end{array}$ & $\begin{array}{l}-0.014 * * \\
(0.007)\end{array}$ \\
\hline PLP/left-labor power & $\begin{array}{c}0.068 \\
(0.093)\end{array}$ & $\begin{array}{r}1.03^{* *} \\
(0.476)\end{array}$ \\
\hline Elderly population & $\begin{array}{l}0.134^{* * *} \\
(0.052)\end{array}$ & $\begin{array}{l}0.427^{* * *} \\
(0.112)\end{array}$ \\
\hline Unemployment & $\begin{array}{l}0.068^{* * *} \\
(0.019)\end{array}$ & $\begin{array}{l}0.067^{* * *} \\
(0.016)\end{array}$ \\
\hline Adjusted $R^{2}$ & .986 & .981 \\
\hline$N$ & 350 & 322 \\
\hline
\end{tabular}

Note: Fixed-effects regression estimates. Figures in parentheses are standard errors.

'The left-labor index is Garrett's measure of left-labor power (LLP) in OECD countries. Garrett, 1998.

$$
\begin{aligned}
& * * * p<.01 \\
& *_{p} p<.05 \\
& { }_{p} p<.10
\end{aligned}
$$

problems as those in developing countries. Comparing results from the LDCs suggests that developed countries have stronger institutions and the appropriate political apparatus to protect their citizens from the adverse effects of globalization. In addition, in agreement with Pierson, the significance of the elderly population and unemployment variables indicates that labor is only one of several welfare beneficiaries that can successfully resist government penchants for welfare-state retrenchment. $^{84}$ 
These findings also more fully expose the explanatory power of the determining variable, that is, PLP. Expectations about the appropriateness of applying this new measure of labor strength to assess changes in government welfare expenditures in this era of globalization have been confirmed. The results are consistent with Garrett's fully specified model, which demonstrates the positive effects of globalization in countries that do not enjoy a comparative advantage in labor. Thus the statistical evidence presented here supports the theory that the political-structural differences between rich and poor countries drive different domestic outcomes in the contemporary era of globalization.

Significantly, year effects mattered for welfare expenditures in OECDs, just as they did in LDCs. This challenges the credibility of the conjecture that the more a nation spends on welfare as a percentage of GDP, the more susceptible its social programs will be to global economic shocks. Developed countries spend a high average of 15 percent of their GDP on welfare expenditures-almost five times the average spent in LDCs.

One rival explanation of my findings might be that the need for social-welfare expenditures in LDCs is declining with international market exposure. It might be thought that globalization is improving employment and incomes, and thus there should be less demand for government welfare protection. Yet it is fairly well-established in the literature that high levels of inequality and social deprivation continue to persist in most of these countries. ${ }^{85}$ Besides, it would be difficult to conclude that welfare-state expansionism in developed countries means that citizens of these countries are in greater need of social protection than the citizens of LDCs.

\section{Implications}

Does the conventional wisdom that globalization adversely affects welfare spending hold true in LDCs? This investigation of fifty-three LDCs from 1972 to 1995 shows that welfare spending in these countries does indeed respond to greater trade flows and capital mobility. These findings challenge others who do not show that globalization affects welfare spending in developed and developing nations differently. Growing numbers of low-skilled workers relative to skilled workers, coupled with large surplus-labor populations, exacerbate the collective-action problems of labor in LDCs and make it increasingly difficult for them to organize. When confronted with the pressures of globalization, workers in LDCs are less capable of defending their welfare benefits than workers in OECD countries, where the organizing potential of labor is relatively 
strong and existing institutions can help workers overcome their collectiveaction problems. Thus, the findings suggest that the difference in welfare-state outcomes is due to a wide disparity in the bargaining power of labor in developed and developing countries. Workers' potential political gains from expanded trade and investment are ultimately outweighed in LDCs by their inability to collectively pressure the government for social programs in their favor.

In an era when many analysts are prodding LDCs to follow the path of newly industrialized countries, the findings here suggest an important cautionary note. Much of a country's successful development depends on a nation's ability to utilize its labor capacity, upgrade the skills of its workforce, and foster the development of strong political institutions. Currently, industrializing LDCs that maintain large surplus labor forces, are less democratic, and have an abundance of low-skilled workers may be reluctant to move up the technological ladder. Unless measures are taken to address these factors, it is possible that, given the competitive conditions of today's world economy, political and social development for these cheap-labor countries will proceed relatively slowly.

Yet it is not too soon to apply to the developing world optimistic visions that "in the global economy ... citizens still have a real choice to make about how to govern the market." 86 Interestingly, my analysis shows that there are political factors (such as strong labor power and democracy) that can positively affect welfare spending in this era of globalization. By recognizing that politics and institutions do matter, I have shown that welfare-state retrenchment is a consequence of the failure of politics to intervene in the economy. Minimizing the trade-off between thriving capitalism and social welfare in developing economies can be accomplished through greater political and institutional development. Labor's political influence ultimately depends on workers' ability to organize and capacity to affect electoral outcomes. Thus an important challenge facing LDCs today is to reconcile international competitiveness with a democratic environment that allows autonomous labor market institutions to flourish.

This article represents the first attempt to explain both the political and international economic constraints on social spending in developing countries. A next step would be to investigate how other facets of social spending (health, education, and housing, for instance) might be reacting to globalization. Will spending on social ventures that contribute more directly to competitiveness increase with globalization? What are the various types of domestic political institutions that can successfully protect citizens of LDCs from the volatility of international markets? There are substantial payoffs both for identifying the most suitable social programs for developing countries in this era of globalization and for understanding the political environment in which they will prosper. 


\title{
Appendix A: Data Sources, Measurements, and Definitions
}

\author{
TABLE A1. Data sources and definitions
}

\begin{tabular}{|c|c|c|}
\hline Concepts ${ }^{\mathrm{a}}$ & Measurements & Definition \\
\hline $\begin{array}{l}\text { Government welfare } \\
\text { expenditures [WELF] }\end{array}$ & $\begin{array}{l}\text { Social security and welfare as a } \\
\text { percentage of GDP } \\
\text { (dependent variable) } \\
\text { Social security and welfare as a } \\
\text { percentage of total } \\
\text { government spending (second } \\
\text { dependent variable) } \\
\text { Special welfare expenditures per } \\
\text { capita }\end{array}$ & $\begin{array}{l}\text { "Social security" consists of income transfers } \\
\text { and providing benefits in cash or in kind for } \\
\text { old age, invalidity, or death, and for } \\
\text { survivors, sickness and maternity, work } \\
\text { injury, unemployment, family allowance, and } \\
\text { health care. "Welfare affairs and services" is } \\
\text { defined as assistance delivered to clients or } \\
\text { groups of clients with special needs, such as } \\
\text { the young, the old, or the disabled. }\end{array}$ \\
\hline $\begin{array}{l}\text { Globalization } \\
{[\text { TRADE] }(-)} \\
{[\text { KFLOW] }(-)}\end{array}$ & $\begin{array}{l}\text { Amount of total trade (exports }+ \\
\text { imports/GDP); and gross } \\
\text { capital flows as a percentage }\end{array}$ & $\begin{array}{l}\text { Gross capital flows is the sum of all inflows } \\
\text { and outflows, using the finest classifications } \\
\text { to avoid netting }\end{array}$ \\
\hline $\begin{array}{l}\text { Potential labor power } \\
\text { [PLP] }(-)\end{array}$ & $\begin{array}{l}\text { of GDP } \\
\text { (Ratio of the numbers employed } \\
\text { in skill-intensive } \\
\text { manufacturing industries } \\
\text { relative to numbers employed } \\
\text { in low-skill manufacturing } \\
\text { industries)* } \\
\text { ( } 1 \text { divided by the number of } \\
\text { surplus laborers in the } \\
\text { economy) }\end{array}$ & $\begin{array}{l}\text { "Low-skilled" refers to those who have no } \\
\text { more than primary or secondary education } \\
\text { and are likely to be employed in labor- } \\
\text { intensive manufacturing industries. "Skilled" } \\
\text { refers to those with more than a basic } \\
\text { general education and usually employed in } \\
\text { heavy and high-skill manufacturing } \\
\text { industries. "Surplus labor" is the total } \\
\text { working-age population (between } 15 \text { and } 65 \\
\text { years of age) minus the total labor force } \\
\text { minus students enrolled in secondary and } \\
\text { post-secondary education. This total is taken } \\
\text { as a percentage of the economically active } \\
\text { population. }\end{array}$ \\
\hline $\begin{array}{l}\text { Demographic variables } \\
\text { [DEPEN] }(+) \\
\text { [URBAN] }(+)\end{array}$ & $\begin{array}{l}\text { Age-dependency ratio; urban } \\
\text { population as a percentage of } \\
\text { total population }\end{array}$ & $\begin{array}{l}\text { "Age dependency ratio" is the number of } \\
\text { persons over } 60 \text { years old divided by number } \\
\text { of persons aged } 20 \text { to } 59 \text {. "Urbanization" is } \\
\text { the midyear population of areas defined as } \\
\text { urban in each country and is measured as the } \\
\text { percentage of the total population. }\end{array}$ \\
\hline $\begin{array}{l}\text { Economic development } \\
{[\mathrm{GDP}](+)} \\
{[\mathrm{SOE}](+)} \\
{[\mathrm{DEBT}](-)}\end{array}$ & $\begin{array}{l}\text { GDP per capita [GDP]; revenue } \\
\text { of state-owned enterprises } \\
\text { [SOE]; total debt service } \\
\text { [DEBT]. }\end{array}$ & $\begin{array}{l}\text { "GDP" is the total GDP of a country divided } \\
\text { by total population, measured in } 1995 \\
\text { constant U.S. dollars. "SOE" economic } \\
\text { activity is the value added of state } \\
\text { enterprises, estimated as their sales revenue } \\
\text { minus the cost of their intermediate inputs. } \\
\text { Total "debt" service is the sum of principal } \\
\text { repayments and interest paid in foreign } \\
\text { currency, goods, or services on long-term } \\
\text { debt and interest payments only on short- } \\
\text { term debt. }\end{array}$ \\
\hline $\begin{array}{l}\text { Political development } \\
{[\text { DEMOC }](+)}\end{array}$ & Indicator of democracy & $\begin{array}{l}\text { Using scale of } 0 \text { to } 10 \text {, with } 10 \text { representing } \\
\text { strong democracy; indicator is derived from } \\
\text { the codings of the competitiveness of } \\
\text { political participation, the openness and } \\
\text { competitiveness of executive recruitment, } \\
\text { and constraints on the chief executive. }\end{array}$ \\
\hline
\end{tabular}

${ }^{\text {a }}$ The expected direction of the relationship (either positive or negative) is shown in parentheses. 


\section{Data Sources for Variables}

DEMOC: Jaggers and Gurr 1994.

KFLOW: IMF, Balance of Payments Statistics, various years. These include direct investment abroad, direct investment in country, portfolio investment and other investments (including trade credits, loans, currency, and deposits). Early editions (early 1970s) include some counting of nonproduced, nonfinancial assets in estimations of the financial account.

SKILL: Classification scheme developed by Wood and Mayer 1998. Their export product classifications are based on the Standard International Trade Classification (SITC, rev. 2). The following list shows which International Standard Industrial Classification (ISIC) codes correspond to the SITC codes (also supplied by Wood and Mayer 1998). The employment statistics for each manufacturing sector came from UNIDO Database of Industrial Statistics. The final value of sKILL is based on the total number of workers employed in high-skilled manufacturing production/low-skilled manufacturing production.

SURP, DEPEN, GDP, SOE, DEBT: World Bank, World Development Indicators, various years. TRADE: World Bank, World Development Indicators, various years.

WELF: IMF, Government Finance Statistics and International Finance Statistics, various years.

TABLE A2. Manufactured exports

\begin{tabular}{|c|c|c|c|}
\hline & SITC2 categories & Translated to manufactured production & ISICI categories \\
\hline Low-skill manufactures & & Low-skill manufacturing production & \\
\hline $\begin{array}{l}\text { 1. Leather and rubber } \\
\text { products }\end{array}$ & $61-62$ & 1. Leather and rubber products & 323,355 \\
\hline 2. Wood and paper products & $63-64$ & $\begin{array}{l}\text { 2. Wood products, except furniture; } \\
\text { paper and paper products }\end{array}$ & 331,341 \\
\hline $\begin{array}{l}\text { 3. Textiles, clothing, } \\
\text { footwear, and travel } \\
\text { goods }\end{array}$ & $65,83-85$ & $\begin{array}{l}\text { 3. Textiles; leather products; wearing } \\
\text { apparel, except footwear; footwear, } \\
\text { except rubber or plastic }\end{array}$ & $\begin{array}{l}321,323,322 \\
\quad 324\end{array}$ \\
\hline $\begin{array}{l}\text { 4. Nonmetallic mineral } \\
\text { products }\end{array}$ & (66 less 667) & $\begin{array}{l}\text { 4. Other nonmetallic mineral products; } \\
\text { glass and products; pottery, china, } \\
\text { and earthenware }\end{array}$ & $369,362,361$ \\
\hline $\begin{array}{l}\text { 5. Iron and steel and metal } \\
\text { products }\end{array}$ & 67,69 & $\begin{array}{l}\text { 5. Iron and steel; fabricated metal } \\
\text { products }\end{array}$ & 371,381 \\
\hline $\begin{array}{l}\text { 6. Fumiture and plumbing } \\
\text { equipment }\end{array}$ & $81-82$ & 6. Furniture, except metal & 332 \\
\hline 7. Ships, bicycles, and trains & $\begin{array}{c}78(\text { less } 781-784) \\
79(\text { less } 792)\end{array}$ & - & \\
\hline 8. Miscellaneous & $\begin{array}{l}89,9 \text { (less } 941 \\
971)\end{array}$ & $\begin{array}{l}\text { 8. Plastic products; other manufactured } \\
\text { products }\end{array}$ & 356,390 \\
\hline High-skill manufactures & & High-skill manufacturing production & \\
\hline 9. Chemicals & $\begin{array}{l}5 \text { (less } 522.24 \\
522.56,524)\end{array}$ & $\begin{array}{l}\text { 9. Industrial chemicals; other chemicals; } \\
\text { misc. petroleum and coal products; } \\
\text { plastic products }\end{array}$ & $\begin{array}{l}351,352,354 \\
356\end{array}$ \\
\hline 10. Cut diamonds & 667.29 & + & \\
\hline 11. Nonelectrical machinery & $71-74$ & $\begin{array}{l}\text { 11. Fabricated metal products; } \\
\text { machinery, except electrical; } \\
\text { machinery, electrical }\end{array}$ & $382,383,384$ \\
\hline
\end{tabular}


TABLE A2. continued

12. Computers and office equipment

13. Communication equipment

14. Electrical machinery

15. Motor vehicles and aircraft

16. Scientific instruments, watches, and cameras
75

76

77

$781-784,792$

87,88

Note: The SITC 5-8 categories allocated to primary rather than manufactured exports are phosphorus pentoxide and phosphoric acids (522.24); aluminum hydroxide (522.56); radioactive material (524); pearls and precious stones, except cut diamonds (667 except 667.29); and nonferrous metals (68).

\section{Appendix B}

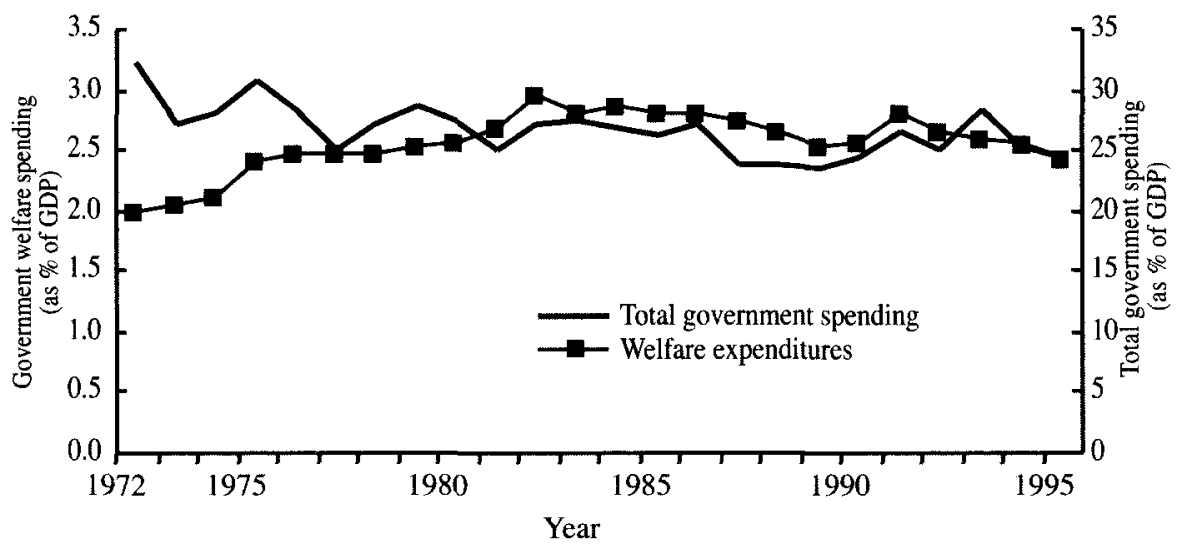

FIGURE B1. The difference between total government spending and welfare spending

Sources: IMF, International Finance Statistics and Government Finance Statistics, various years.

\section{Appendix C: Comparisons of PLP with Other Indicators}

Few efforts have been made to measure and compare labor power across countries. Union density is most commonly used in cross-national comparisons of labor power, sometimes also 
TABLE C1. Comparative Assessments of Labor Strength

\begin{tabular}{|c|c|c|c|c|}
\hline Country & $P L P$ & Collier and Collier (1979)* & Valenzuela $(1989)^{*}$ & Cook (1998) \\
\hline \multicolumn{5}{|l|}{ Argentina } \\
\hline $1970 \mathrm{~s}$ & High & Strong & Strong & \\
\hline $1980 \mathrm{~s}$ & High & & Strong & \\
\hline $1990-95$ & High & & & \\
\hline Overall & High & & & Strong \\
\hline \multicolumn{5}{|l|}{ Brazil } \\
\hline $1970 \mathrm{~s}$ & Medium & Moderate-weak & Weak & \\
\hline $1980 \mathrm{~s}$ & Medium & & Weak & \\
\hline $1990-95$ & High & & & \\
\hline Overall & Medium & & & Medium \\
\hline \multicolumn{5}{|l|}{ Chile } \\
\hline $1970 \mathrm{~s}$ & Medium & Moderate-strong & & \\
\hline $1980 \mathrm{~s}$ & Low & & & \\
\hline $1990-95$ & Medium & & & \\
\hline Overall & Medium & & & Low \\
\hline \multicolumn{5}{|l|}{ Colombia } \\
\hline $1970 \mathrm{~s}$ & Low & & & \\
\hline $1980 \mathrm{~s}$ & Medium & & & \\
\hline $1990-95$ & High & & & \\
\hline Overall & Medium & & & Low \\
\hline \multicolumn{5}{|l|}{ Dominican Republic } \\
\hline $1970 \mathrm{~s}$ & Low & & Weak & \\
\hline $1980 \mathrm{~s}$ & Medium & & Weak & \\
\hline $1990-95$ & & & & \\
\hline Overall & Medium & & & \\
\hline \multicolumn{5}{|l|}{ Ecuador } \\
\hline $1970 \mathrm{~s}$ & Low & & Weak & \\
\hline $1980 \mathrm{~s}$ & Medium & & Weak & \\
\hline $1990-95$ & Medium & & & \\
\hline Overall & Medium & & & \\
\hline \multicolumn{5}{|l|}{ Mexico } \\
\hline $1970 \mathrm{~s}$ & Medium & Moderate-strong & & \\
\hline $1980 \mathrm{~s}$ & High & & & \\
\hline $1990-95$ & High & & & \\
\hline Overall & High & & & Medium \\
\hline \multicolumn{5}{|l|}{ Philippines } \\
\hline $1970 \mathrm{~s}$ & High & & Weak & \\
\hline $1980 \mathrm{~s}$ & Medium & & Weak & \\
\hline $1990-95$ & High & & & \\
\hline Overall & Medium & & & \\
\hline \multicolumn{5}{|l|}{ Venezuela } \\
\hline $1970 \mathrm{~s}$ & Medium & & & \\
\hline $1980 \mathrm{~s}$ & Medium & & & \\
\hline $1990-95$ & Medium & & & \\
\hline Overall & Medium & & & Medium \\
\hline
\end{tabular}

Note: Neither Collier and Collier nor Valenzuela specify the exact years for their labor-strength ratings. Cook's more recent analysis does not mention dates of coverage.

in combination with measures of union centralization and unity. As noted earlier, union density is more appropriately applied in the developed world than in LDCs. The normal factors granting unions bargaining power in the developed economies (such as tight labor 
markets, stable economic growth, freedom from government control, organizational density and strength, and financial resources) are conspicuously absent in the developing world.

It is of no surprise, therefore, that the correlation between PLP and union-density levels is very low $(0.04) .{ }^{87}$ Most LDCs are still far from attaining strong and independent unions such as those that commonly exist in the developed world. Collective-action problems continue to exist in countries with high union density where labor is rife with internal divisions and still subject to many governmental controls. ${ }^{88}$ In contrast, as skill levels increase and surplus labor is slowly absorbed, the labor movement may organize underground and reach beyond state-controlled unions to ally with other members of the working class (as has occurred in Brazil and Korea). ${ }^{89}$

Comparing PLPindicators to other qualitative assessments of labor power is a more precise method for assessing the usefulness of this new indicator. Most of this literature is dominated by historical-interpretative approaches to assess labor strength. Table $\mathrm{C} 1$ lists a few rare studies that, to my knowledge, have attempted to assess the magnitude of labor power and compare it with other countries, albeit mostly in the same region-Latin America. These comparative analyses of labor use multiple indicators of labor's strength, such as the extent of state control over labor, party affiliation, and level of decentralization.

The rankings in Table $\mathrm{Cl}$ should be interpreted with some caution. The primary problem with comparing these qualitative indicators to PLP is that the indicators are static measures of labor strength. In addition, note that in Collier and Collier's and Valenzuela's studies, the rankings were not indexed and, thus, are subject to some interpretation by the authors. The PLP indicator was ranked high, medium, or low according to the 75th, 50th, and 25th percentiles, respectively.

Table $\mathrm{Cl}$ serves to increase confidence in the reliability of PLP as a measure of labor power. None of the qualitative rankings differ by more than one grade from the PLP rankings. The Philippine case shows the most contrast, but even Valenzuela acknowledges the complexity of classifying the Philippine labor movement because of labor's links to a broader social base. ${ }^{90}$

Ultimately, using labor power in empirical analyses demands accurate measurement. The indicator proposed in this study, PLP, offers three advantages of a new variable: (1) it corresponds to conditions specific to labor in developing countries, (2) it is comparable across LDCs, and (3) it has a temporal component. The first advantage privileges PLP as an indicator of labor strength because it has its origins in the political and economic situation of labor in LDCs. The desirability of the second two characteristics is more obvious. A standardized measure available over time and across countries greatly reduces the biases that can affect empirical analyses.

\section{References}

Agenor, Pierre Richard, and Peter J. Montiel. 1996. Development Macroeconomics. Princeton, N.J.: Princeton University Press.

87. Note that these correlations are based on very few observations. Union-density data exists only for 1985 and 1995, and even then a large number of data points are missing. Correlations with McGuire's (1999) Labor Strength Index (based only on 1995 union data) are also low for the same reasons.

88. See Drake 1996; and Banuri and Amadeo 1991.

89. See, for example, Fields 1994; Drake 1996; and Kim 1997.

90. Valenzuela $1989,455$. 
Aghion, Philippe, and Jeffrey G. Williamson. 1998. Growth, Inequality, and Globalization. New York: Cambridge University Press.

Ahmad, Ehtisham, and Athar Hussain. 1991. Social Security in China. In Social Security in Developing Countries, edited by Ehtisham Ahmad and Athar Hussain, 247-304. Oxford: Clarendon Press.

Amirahmadi, Hooshang, and Weiping Wu. 1993. Private Capital Flows and Developing Countries. Journal of Third World Studies 10 (1):327-57.

Atkinson, A. B., and John Hills. 1991. Social Security in Developed Countries: Are There Lessons For Developing Countries? In Social Security in Developing Countries, edited by Ehtisham Ahmad and Athar Hussain, 81-111. Oxford: Clarendon Press.

Banuri, Tariq, and Edward Amadeo. 1991. Worlds Within the Third World: Labour Market Institutions in Asia and Latin America. In Economic Liberalization: No Panacea, edited by Tariq Banuri, 171-200. Oxford: Clarendon Press.

Bernauer, Thomas, and Christoph Achini. 2000. From "Real" to "Virtual" States? Integration of the World Economy and Its Effects on Government Activity. European Journal of International Relations 6 (2):223-76.

Brown, David, and Wendy Hunter. 1999. Democracy and Social Spending in Latin America, 1980-92. American Political Science Review 93 (4):779-90.

Brown, Michael, ed. 1988. Remaking the Welfare State. Philadelphia, Pa: Temple University Press.

Cameron, David. 1978. The Expansion of the Public Sector: A Comparative Analysis. American Political Science Review 72 (4): 1243-61.

Campbell, Donald. 1988. Methodology and Epistemology for Social Science. Chicago: University of Chicago Press.

Cerny, Philip. 1995. Globalization and the Changing Logic of Collective Action. International Organization 49 (4):595-625.

Chan, Anita, and Robert Senser. 1997. China's Troubled Workers. Foreign Affairs 76(2):104-17.

Chuhan, Punam, Stijn Claessens, and Nlandu Mamingi. 1993. Equity and Bond Flows to Latin America and Asia: The Role of Global and Country Factors. World Bank Policy Research Working Paper 1160. Washington, D.C.: World Bank.

Clayton, Richard, and Jonas Pontusson. 1998. Welfare State Retrenchment Revisited. World Politics 51 (1):67-98.

Collier, Ruth B., and David Collier. 1979. Inducements Versus Constraints: Disaggregating "Corporatism." American Political Science Review 73 (4):967-86.

- 1991. Shaping the Political Arena: Critical Junctures, Labor Movement, and Regime Dynamics in Latin America. Princeton, N.J.: Princeton University Press.

Cook, Maria L. 1998. Toward Flexible Industrial Relations? Neo-liberalism, Democracy, and Labor Reform in Latin America. Industrial Relations 37 (3):311-36.

Crisp, Brian. 1994. Limitations to Democracy in Developing Capitalist Societies: The Case of Venezuela. World Development 22 (10):1491-1509.

Dean, Judith M. 1995. From Protectionism to Free Trade Fever? Recent Reforms in Developing Countries. Open Economies Review 6 (4):369-85.

Devarajam, S., Hafez Ghanem, and Karen Thierfelder. 1997. Economic Reforms and Labor Unions: A General Equilibrium Analysis Applied to Bangladesh \& Indonesia. World Bank Economic Review 11 (1): 145-170.

Deyo, Frederic C. 1989. Beneath the Miracle: Labor Subordination in the New Asian Industrialism. Berkeley: University of California Press.

. 1991. Export Manufacturing and Labor: The Asian Case. In Labor in the Capitalist World Economy, edited by Charles Bergquist. London: Sage Publications.

Drake, Paul L. 1996. Labor Movements and Dictatorships: The Southern Cone in Comparative Perspective. Baltimore, Md.: John Hopkins University Press.

Drunberg, Isabelle. 1998. Double Jeopardy, Globalization, Liberalization, and the Fiscal Squeeze. World Development 26 (4):591-605.

Eichengreen, Barry. 1996. Globalizing Capital. Princeton, N.J.: Princeton University Press. 
Esping-Andersen, Gosta. 1990. The Three Worlds of Welfare Capitalism. Princeton, N.J.: Princeton University Press.

—, ed. 1996. Welfare States in Transition. London: Sage Publications.

Evans, Peter. 1997. The Eclipse of the State? Reflections on Stateness in an Era of Globalization. World Politics 50 (1):62-87.

Fields, Gary. 1994. Changing Labor Market Conditions and Economic Development in Hong Kong, the Republic of Korea, Singapore, and Taiwan, China. World Bank Economic Review 8 (3):395-414.

Galenson, Walter. 1962. Introduction. In Labor in Developing Economies, edited by Walter Galenson. Berkeley: University of California Press.

- 1994. Trade Union Growth and Decline: An International Study. Praeger, Westport, CT.

Garrett, Geoffrey. 1998. Partisan Politics in the Global Economy. Cambridge: Cambridge University Press.

- 2001. Globalization and Government Spending Around the World. Studies in Comparative International Development 35 (4):3-29.

Garrett, Geoffrey, and D. Mitchell. 1996. Globalization and the Welfare State: Income Transfers in the Industrial Democracies, 1966-90. Paper presented at the Center for International Studies, University of Southern California, Los Angeles, California.

Gereffi, Gary. 1995. Global Production Systems and Third World Development. In Global Change, Regional Response, edited by Barbara Stallings, 100-42. New York: Cambridge University Press.

Gill, Stephen. 1995. Globalization, Market Civilization, and Disciplinary Neoliberalism. Millenium: Journal of International Studies 24 (3):399-423.

Gray, John. 1998. False Dawn: The Delusions of Global Capitalism. New York: The New Press.

Greider, William. 1998. One World, Ready or Not. New York: Simon and Schuster.

Griffith-Jones, Stephany, and Barbara Stallings. 1995. New Global Financial Trends: Implications for Development. In Global Change, Regional Response, edited by Barbara Stallings, 143-73. New York: Cambridge University Press.

Hadenius, Axel. 1992. Democracy and Development. Cambridge: Cambridge University Press.

Heredia, Blanca. 1997. Prosper or Perish? Development in the Age of Global Capital. Current History $96(613): 383-88$.

Hicks, Alexander. 1999. Social Democracy and Welfare Capitalism. Ithaca, N.Y.: Comell University Press.

Hicks, Alexander M., and Duane H. Swank 1992. Politics, Institutions, and Welfare Spending in Industrialized Democracies, 1960-1982. American Political Science Review. 86 (3):658-74.

Hurrell, Audrey, and Nancy Woods. 1995. Globalization and Inequality. Millenium: Journal of International Studies 24 (3):447-70.

Ingerson, Alice. 1984. The Textile Industry and Working Class Culture. In Labor in the Capitalist World Economy, edited by Charles Bergquist, 217-42. London: Sage Publications.

Iversen, Torben, and Thomas R. Cusack. 2000. The Causes of Welfare State Expansion: Deindustrialization or Globalization? World Politics 52 (April):313-49.

International Monetary Fund (IMF). Various years. Balance of Payments Statistics Yearbook. Washington, D.C.: IMF.

Various years. Government Finance Statistics Yearbook. Washington, D.C.: IMF.

Various years. International Financial Statistics. Washington, D.C.: IMF.

Intriligator, Michael, Ronald Bodkin, and Cheng Hsiao. 1996. Econometric Models, Techniques, and Applications. 2nd ed. Upper Saddle River, N.J.: Prentice Hall.

Jaggers, Keith, and Ted Robert Gurr. 1994. Polity III: Regime Type and Political Authority 1800-1994. Ann Arbor, Mich: Inter-University Consortium for Political and Social Research.

Katzenstein, Peter J. 1995. Small States in World Markets: Industrial Policy in Europe. Ithaca, N.Y.: Cornell University Press.

Kaufman, Robert, and Alex Segura-Ubiergo. 2001. Globalization, Domestic Politics, and Social Spending in Latin America: A Time-Series Cross-Section Analysis, 1973-1997. World Politics 53 (4): 553-587.

Kim, Eun Mee. 1997. Big Business, Strong State: Collusion and Conflict in South Korean Development, 1960-1990. Albany, N.Y.: SUNY Press. 
King, Gary, J. Honaker, A. Joseph, and Ken Scheve. 2001. Analyzing Incomplete Political Science Data: An Alternative Algorithm for Multiple Imputation. American Political Science Review 95 (1):49-70. Korpi, Walter. 1983. The Democratic Class Struggle. London: Routledge and Kegan Paul.

Lake, David A., and Matthew Baum. Forthcoming. The Invisible Hand of Democracy: Political Control and the Provision of Public Services. Comparative Political Studies.

Lewbel, Arthur. 1997. Constructing Instruments for Regressions with Measurement Error when No Additional Data Are Available, with an Application to Patents and R\&D. Econometrica 65 (5):1201-13.

Lok, H. P. 1993. Labour in the Garment Industry: An Employer's Perspective. In Indonesia Assessment, edited by Chris Manning and Joan Hardjono, 155-72. Canberra: Australian National University.

Looney, Robert. 1993. Government Expenditures and Third World Economic Growth in the 1980s: The Impact of Defense Expenditures. Canadian Journal of Development Studies 14 (1):23-42.

Mamingi, Nlandu. 1997. Saving-Investment Correlations and Capital Mobility: The Experience of Developing Countries. Journal of Policy Modeling 19 (6):605-26.

Manning, Chris. 1998. Does Globalization Undermine Labor Standards? Lessons from East Asia. Australian Journal of International Affairs 52 (2):133-47.

Maxfield, Sylvia. 1998. Understanding the Political Implications of Financial Internationalization in Emerging-Market Countries. World Development 26 (7):1201-19.

McGuire, James W. 1997. Peronism Without Peron: Unions, Parties, and Democracy in Argentina. Stanford, Calif.: Stanford University Press.

- 1999. Labor Union Strength and Human Development in East Asia and Latin America. Studies in Comparative International Development 33 (4):3-34.

Mesa-Lago, Carmelo. 1991. Latin America and the Caribbean. In Social Security in Developing Countries, edited by Ehtifham Ahmad, Jean Dreze, Amartya Fen, and John Hills 356-94. Oxford: Oxford University Press.

- 1994. Changing Social Security in Latin America. Boulder, Colo.: Lynne Rienner.

Midgley, James. 1984. Social Security, Inequality, and the Third World. New York: John Wiley and Sons.

Montiel, Peter. 1994. Capital Mobility in Developing Countries: Some Measurement Issues and Empirical Estimates. World Bank Economic Review 8 (3):311-50.

Morris, Robert. 1988. Testing the Limits of Social Welfare. London: Brandeis University Press.

O'Connor, Julia, and Gregg Olsen. 1998. Power Resources Theory and the Welfare State. Toronto: University of Toronto Press.

Olson, Mancur. 1971. The Logic of Collective Action. Cambridge, Mass.: Harvard University Press.

Pfaller, Alfred, Ian Gough, and Goran Therborn. 1991. Can the Welfare State Compete? A Comparative Study of Five Advanced Capitalist Countries. Houndmills, U.K.: Macmillan.

Pierson, Paul. 1996. The New Politics of the Welfare State. World Politics 48 (2):143-79.

Polanyi, Karl. 1944. The Great Transformation. New York: Farrar \& Reinhart.

Quinn, Dennis. 1997. The Correlates of Change in International Financial Regulation. American Political Science Review 91 (3):531-51.

Rieger, Elmar, and S. Leibfried. 1998. Welfare State Limits to Globalization. Politics and Society 26 (3):363-90.

Rodrik, Dani. 1997a. Sense and Nonsense in the Globalization Debate. Foreign Policy 107 (summer): 19-37.

Rodrik, Dani. 1997b. Has Globalization Gone Too Far? Washington, D.C.: Institute for International Economics.

Rodrik, Dani. 1998. Why Do More Open Economies Have Bigger Governments? Journal of Political Economy 106 (5):997-1033.

Rogowski, Ronald. 1989. Commerce and Coalitions. Princeton, N.J.: Princeton University Press.

Rueschemeyer, Dietrich, Evelyne H. Stephens, and John D. Stephens. 1992. Capitalist Development and Democracy. Chicago: University of Chicago Press.

Ruggie, John Gerard. 1982. International Regimes, Transactions, and Change: Embedded Liberalism in Postwar Economic Order. International Organization 36 (2):379-415. 
1994. At Home Abroad, Abroad at Home: International Liberalization and Domestic Stability in the New World Economy. Millenium: Journal of International Studies. 24 (3):507-26.

Ruggles, Patricia, and Michael O'Higgins. 1987. Retrenchment and the New Right: A Comparative Analysis of the Impacts of the Thatcher and Reagan Administrations. In Stagnation and Renewal in Social Policy: The Rise and Fall of Policy Regimes, edited by Martin Rein, Gosta Esping-Andersen, and Lee Rainwater, 160-190. New York: M. E. Sharpe.

Schmidt, Sonke. 1995. Social Security in Developing Countries: Basic Tenets and Fields of State Intervention. International Social Work. 38 (1):7-26.

Shafer, D. Michael. 1994. Winners and Losers. Ithaca, N.Y.: Cornell University Press.

Sherer, M. 1987. Welfare States: An Overview of Problems and Prospects. In Modern Welfare States: A Comparative View of Trends and Prospects edited by Robert R. Friedmann, Neil Gilbert, Moshe Sherer, 290-98. New York: New York University Press.

Strange, Susan. 1997. The Erosion of the State. Current History 96 (613):365-69.

Swank, Duane. 1998. Funding the Welfare State: Globalization and the Taxation of Business in Advanced Market Economies. Political Studies 46 (4):671-92.

Tang, Kwong-Leung. 1996. The Determinants of Social Security in Developing Countries: A Comparative Analysis. International Social Work 39 (4):377-93.

Taylor, Mark, and Lucio Sarno. 1997. Capital Flows to Developing Countries: Long- and Short-Term Determinants. The World Bank Economic Review 11 (3):451-70.

Tyrell, Jr., Emmett. 1977. The Future That Doesn't Work: Social Democracy's Failures in Britain. New York: Doubleday.

United Nations. Various years. UNIDO Database of Industrial Statistics. Vienna: United Nations Industrial Development Organization.

—_. 1992-93. UN Industry and Development Report. Vienna: UN Industrial Development Organization.

US Agency for International Development (US AID) 1999. Global Education Database. Center for Human Capacity Development. Washington, DC.

Usui, Chikako. 1994. Welfare State Development in a World System Context: Event History Analysis of First Historical Social Insurance Legislation Among 60 Countries, 1880-1960. In The Comparative Political Economy of the Welfare State, edited by Thomas Janoski and A. Hicks, 254-77. Cambridge: Cambridge University Press.

Valenzuela, Samuel. 1989. Labor Movements in Transitions to Democracy. Comparative Politics 21(4): 445-72.

Van Hear, Nicholas. 1988. Recession, Retrenchment, and Military Rule: Nigerian Labor in the 1980s. In Trade Unions and the New Industrialization of the Third World, edited by Roger Southall, 144-63. Pittsburgh, Pa.: University of Pittsburgh Press.

Wahl, Ana-Maria. 1994. Economic Development and Social Security in Mexico, 1945-1985. International Journal of Contemporary Sociology 35:59-81.

Wicks, Malcolm. 1987. A Future for All: Do We Need A Welfare State? New York: Viking Penguin.

Wood, Adrian. 1994. North-South Trade, Employment, and Inequality. New York: Oxford University Press.

- 1995. How Trade Hurt Unskilled Workers. Perspectives 9(3): 57-80.

- 1997. Openness and Wage Inequality in Developing Countries: The Latin American Challenge to East Asian Conventional Wisdom. World Bank Economic Review 11 (1):33-57.

Wood, Adrian, and K. Berge. 1997. Exporting Manufactures: Human Resources, Natural Resources, and Trade Policy. The Journal of Development Studies 34 (1):35-59.

Wood, Adrian, and Jorg Mayer. 1998. Africa's Export Structure in a Comparative Perspective. In UN Conference on Trade and Development, African Development in a Comparative Perspective, study no.

4. Geneva: United Nations. Available at 〈www.ids.ac.uk/ids/global/pdfs/afex.pdf〉.

World Bank. Various years. World Development Indicators. Washington, D.C.: World Bank.

World Bank Policy Research Report. 1994. Averting the Old Age Crisis. Oxford: Oxford University Press. 